University of Nebraska - Lincoln

DigitalCommons@University of Nebraska - Lincoln

\title{
Insights from a synthesis of old and new climate-proxy data from the Pyramid and Winnemucca lake basins for the period 48 to $11.5 \mathrm{cal} \mathrm{ka}$
}

Larry Benson

U.S. Geological Survey, great.basin666@gmail.com

J.P. Smoot

U.S. Geological Survey, jpsmoot@usg.gov

S.P. Lund

University of Southern California, slund@usc.edu

S.A. Mensing

University of Nevada

F.F. Foit Jr.

Washington State University

See next page for additional authors

Follow this and additional works at: https://digitalcommons.unl.edu/usgsstaffpub

Benson, Larry; Smoot, J.P.; Lund, S.P.; Mensing, S.A.; Foit, F.F. Jr.; and Rye, R.O., "Insights from a synthesis of old and new climate-proxy data from the Pyramid and Winnemucca lake basins for the period 48 to 11.5 cal ka" (2012). USGS Staff -- Published Research. 727.

https://digitalcommons.unl.edu/usgsstaffpub/727

This Article is brought to you for free and open access by the US Geological Survey at DigitalCommons@University of Nebraska - Lincoln. It has been accepted for inclusion in USGS Staff -- Published Research by an authorized administrator of DigitalCommons@University of Nebraska - Lincoln. 


\section{Authors}

Larry Benson, J.P. Smoot, S.P. Lund, S.A. Mensing, F.F. Foit Jr., and R.O. Rye 


\title{
Insights from a synthesis of old and new climate-proxy data from the Pyramid and Winnemucca lake basins for the period 48 to $11.5 \mathrm{cal}$ ka
}

\author{
L.V. Benson ${ }^{a, *, 1}$, J.P. Smoot ${ }^{b}$, S.P. Lund ${ }^{c}$, S.A. Mensing ${ }^{d}$, F.F. Foit Jr. ${ }^{e}$, R.O. Rye ${ }^{f}$ \\ ${ }^{a}$ U.S. Geological Survey, 602 Pine St, Boulder, CO 80302, USA \\ ${ }^{\mathrm{b}}$ U.S. Geological Survey, MS 955, Reston, VA 22092, USA \\ ${ }^{\mathrm{c}}$ Department of Earth Sciences, University of Southern California, Los Angeles, CA 90089, USA \\ ${ }^{\mathrm{d}}$ Department of Geography, University of Nevada, Reno, NV 89557, USA \\ e School of Earth and Environmental Sciences, Washington State University, Pullman, WA 99163, USA \\ ${ }^{\mathrm{f}}$ U.S. Geological Survey, MS 963, Denver Federal Center, Lakewood, CO 80225, USA
}

\section{A R T I C L E I N F O}

Article history:

Available online $\mathrm{xxx}$

\begin{abstract}
A B S T R A C T
A synthesis of old and new paleoclimatic data from the Pyramid and Winnemucca lake basins indicates that, between 48.0 and $11.5 \cdot 10^{3}$ calibrated years BP (hereafter ka), the climate of the western Great Basin was, to a degree, linked with the climate of the North Atlantic. Paleomagnetic secular variation (PSV) records from Pyramid Lake core PLC08-1 were tied to the GISP2 ice-core record via PSV matches to North Atlantic sediment cores whose isotopic and(or) carbonate records could be linked to the GISP2 $\delta^{18} \mathrm{O}$ record. Relatively dry intervals in the western Great Basin were associated with cold Heinrich events and relatively wet intervals were associated with warm Dansgaard-Oeschger (DO) oscillations. The association of western Great Basin dry events with North Atlantic cold events (and vice versa) switched sometime after the Laurentide Ice Sheet (LIS) reached its maximum extent. For example, the Lahontan highstand, which culminated at $15.5 \mathrm{ka}$, and a period of elevated lake level between 13.1 and $11.7 \mathrm{ka}$ were associated with cold North Atlantic conditions, the latter period with the Youngest Dryas event. Relatively dry periods were associated with the Bølling and Allerød warm events. A large percentage of the LIS may have been lost to the North Atlantic during Heinrich events 1 and 2 and may have resulted in the repositioning of the Polar Jet Stream over North America. The Trego Hot Springs, Wono, Carson Sink, and Marble Bluff tephras found in core PLC08-1 have been assigned GISP2 calendar ages of respectively, 29.9, 33.7, 34.1, and 43.2 ka. Given its unique trace-element chemistry, the Carson Sink Bed is the same as Wilson Creek Ash 15 in the Mono Lake Basin. This implies that the Mono Lake magnetic excursion occurred at approximately $34 \mathrm{ka}$ and it is not the Laschamp magnetic excursion.

The entrance of the First Americans into the northern Great Basin is dated to approximately $14.4 \mathrm{ka}$, a time when the climate was relatively dry. Evidence for human occupation of the Great Basin is lacking for the next 1100 years (y); i.e., the oldest western stemmed point site in the Great Basin dates to $13.3 \mathrm{ka}$. Two hypotheses are suggested for this cultural hiatus: (1) the climate had deteriorated to the point that people vacated the Great Basin, or (2) people moved to basin-bottom wetlands that persisted during the dry period, and then the subsequent Younger Dryas wet event erased the archaeological evidence deposited around the low-elevation wetland sites.
\end{abstract}

(c) 2012 Elsevier Ltd and INQUA. All rights reserved.

\section{Introduction}

For sometime there has been a need to develop and compare high-resolution lake-based records of climate change across the

\footnotetext{
* Corresponding author.

E-mail address: lbenson@usgs.gov (L.V. Benson)

1 L.V. Benson is a USGS emeritus, an affiliate of the Institute of Arctic and Alpine Research and an adjunct curator of anthropology at the Museum of Natural History, University of Colorado.
}

western United States and, in particular, within the boundaries of the Great Basin (Fig. 1). In this paper, high-resolution is used as a relative term. For records $100 \mathrm{y}$ in length, high resolution is taken to indicate data accumulated over 1-to-5-y intervals; for a 10,000 y record, high resolution is taken to indicate data accumulated over $\sim 10$-y intervals, and for a 100,000 y record, high resolution is taken to indicate data accumulated over 50-to-150-y intervals.

To a great extent, researchers have been limited by three factors: (1) the existence of sites having long continuous records of climate

1040-6182/\$ - see front matter (c) 2012 Elsevier Ltd and INQUA. All rights reserved. doi:10.1016/j.quaint.2012.02.040

This article is a U.S. government work, and is not subject to copyright in the United States. 


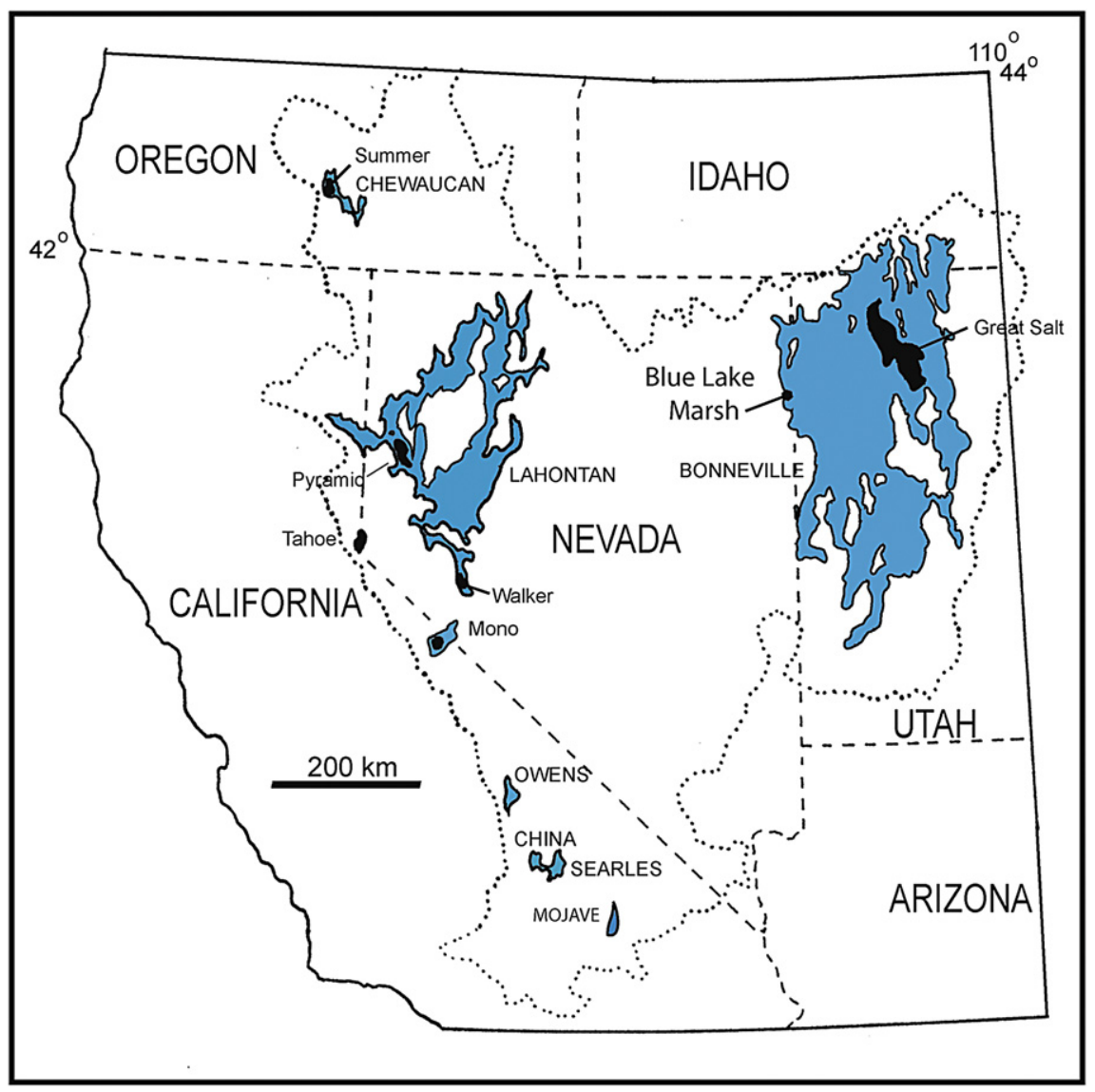

Fig. 1. Major Pleistocene lake systems in the Great Basin (shown enclosed by dotted line) of the western United States.

change, (2) the inherent inaccuracy of sediment dating methods, which hinders precise intercomparison of western lake-based climate records, and (3) budget.

Although little can be done about factor (3), this paper presents a study that attempts to come to grips with the first two factors. In this paper, new and previously published climate-proxy data sets from two western Lahontan basins (Pyramid and Winnemucca lake basins shown in Figs. 2 and 3 ) are compared in order to produce a comprehensive treatment of change in the hydrologic balance of Lake Lahontan (Fig. 3) for the period 48.0 to $11.5 \mathrm{ka}$. The western Lahontan Basin includes Pyramid Lake, Winnemucca Lake, Honey Lake, and the Smoke Creek-Black Rock Desert basins (see Supplementary Fig. 1). A discontinuous mostly tufa-based record of minimum lake level is combined with continuous sediment-based proxy records of relative lake level. The lake-level envelope was created, using subaerially exposed ${ }^{14} \mathrm{C}$-dated materials some of which were deposited under water (carbonate tufas) and some of which were deposited and preserved in the subaerial environment (e.g., archaeological textiles, woody material, animal dung; Benson and Thompson, 1987).

New climate-proxy data sets and the sedimentology of two sediment cores (PLC08-1 and PL97-3) are presented. Core PLC08-1 was taken near the former site of core PLC92B (Fig. 3) in order to create a PSV-based age model for PLC08-1, which could then be transferred to PLC92B, using the total inorganic carbon (TIC) and oxygen-18 $\left(\delta^{18} \mathrm{O}\right)$ records common to both cores. Core PL97-3 was taken from a relatively deep area in Pyramid Lake (Fig. 3) in order to extend the PLC92B record forward in time.

Steve Lund (in Benson et al., 1998) was the first to use PSV records to associate intervals within a sedimentary sequence with (H) events recorded in North Atlantic ice cores and marine sediments. The data he produced indicated that three of four persistent Mono Lake lowstands were associated with Heinrich events $\mathrm{H} 4, \mathrm{H} 2$, and $\mathrm{H} 1$. In the same manner, more detailed PSVbased age models for PLC92B and PLC08-1 allow, for the first time, a direct comparison between changes in the hydrologic balance of Lake Lahontan and changes in $\delta^{18} \mathrm{O}$ (air temperature) recorded in the Greenland GISP2 ice core (Stuiver and Grootes, 2000) for the period $49.3-13.9 \mathrm{ka}$, without reliance on ${ }^{14} \mathrm{C}$-based sediment-age determinations that suffer from complications associated with reservoir effect and reworking of old carbon. $49.3 \mathrm{ka}$ is the oldest dated sediment in PLC08-1 and 13.9 is the youngest dated sediment in PLC92B. Age models for the lake-level envelope and for the PLC97-3 climate-proxy data sets are based on calibrated ${ }^{14} \mathrm{C}$ determinations (Stuiver et al., 2005).

The PLC08-1 proxy-climate data sets also are compared to previously published (Benson et al., 2011) high-resolution proxyclimate data sets from the Bonneville Basin (Fig. 1), which also were registered within a PSV-based age model.

\section{Methods}

\subsection{Coring, sediment sampling, age control, and analytical methods}

\subsubsection{PLC92B}

PLC92B was recovered in $7.1 \mathrm{~m}$ of water from the northwest corner (Wizards Cove) of Pyramid Lake (Fig. 3) in 1992, using a modified Livingstone coring device. Continuous 5-cm-thick samples were taken from the $17.35-\mathrm{m}$ core, freeze-dried, and homogenized. Salts formed during the drying process were removed by repeated washes in deionized water prior to determination of $\delta^{18} \mathrm{O}, \delta^{13} \mathrm{C}$, total carbon (TC), and TIC (see Benson et al., 


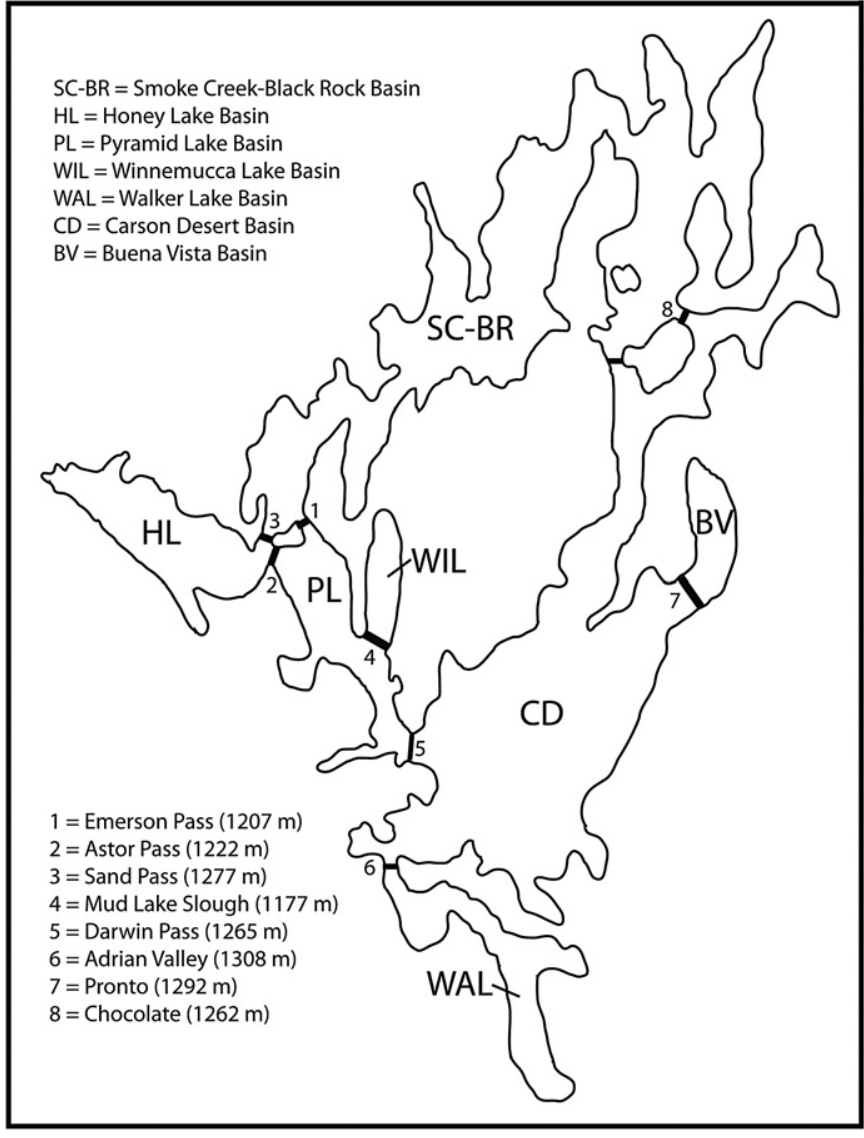

Fig. 2. Outline of the Lahontan Basin, showing seven lake basins and eight spill points (depicted as black bars).

1997 for a detailed discussion of the analytical procedures). Stable isotope and carbon data for this core have been listed in Supplementary Table 1 .

\subsubsection{PLCO8-1}

A modified Livingstone coring device was used to recover $16.85 \mathrm{~m}$ of sediment (core PLC08-1) from $6.2 \mathrm{~m}$ of water in the Wizards Cove area of Pyramid Lake (Fig. 3, UTM coordinates 11T 2700614444701 ) in 2008. The sedimentary records from PLC92B and PLC08-1 lack the Holocene time period because these sediments were eroded by wave action once Pyramid Lake fell below its spill point to the Winnemucca Lake basin. Analyses of $\delta^{18} \mathrm{O}$ and TIC were performed on continuous 4-cm-thick sections of the core in order to provide a means of correlation between depths in PLC08-1 and PLC92B. Most of the isotopic analyses and all the TIC analyses were performed at the Limnological Research Center (LRC) at the University of Minnesota. Thirty-nine of the isotopic analyses were performed at the SUNY-Albany isotope facility. Correlation of TIC and $\delta^{18} \mathrm{O}$ values as a function of depth are illustrated in Supplementary Fig. 1, listed in Supplementary Table 2, and plotted in Fig. 4A.

A PSV-based age model for PLC08-1 (Fig. 4B) was created using 100 matches in inclination, declination, and intensity values between PLC08-1 and Late Pleistocene marine PSV records that span the interval 10-70 ka (Lund and Keigwin, 1994; Lund et al., 2001a, 2001b). The marine PSV records were then linked to the GISP2 chronology by correlating oxygen-isotope data and distinctive sedimentological variability in the deep-sea cores (Johnson et al., 1988; Keigwin and Jones, 1994) to the GISP2 $\delta^{18} \mathrm{O}$ record. The PLC08-1 climate-proxy data have been plotted versus calendar

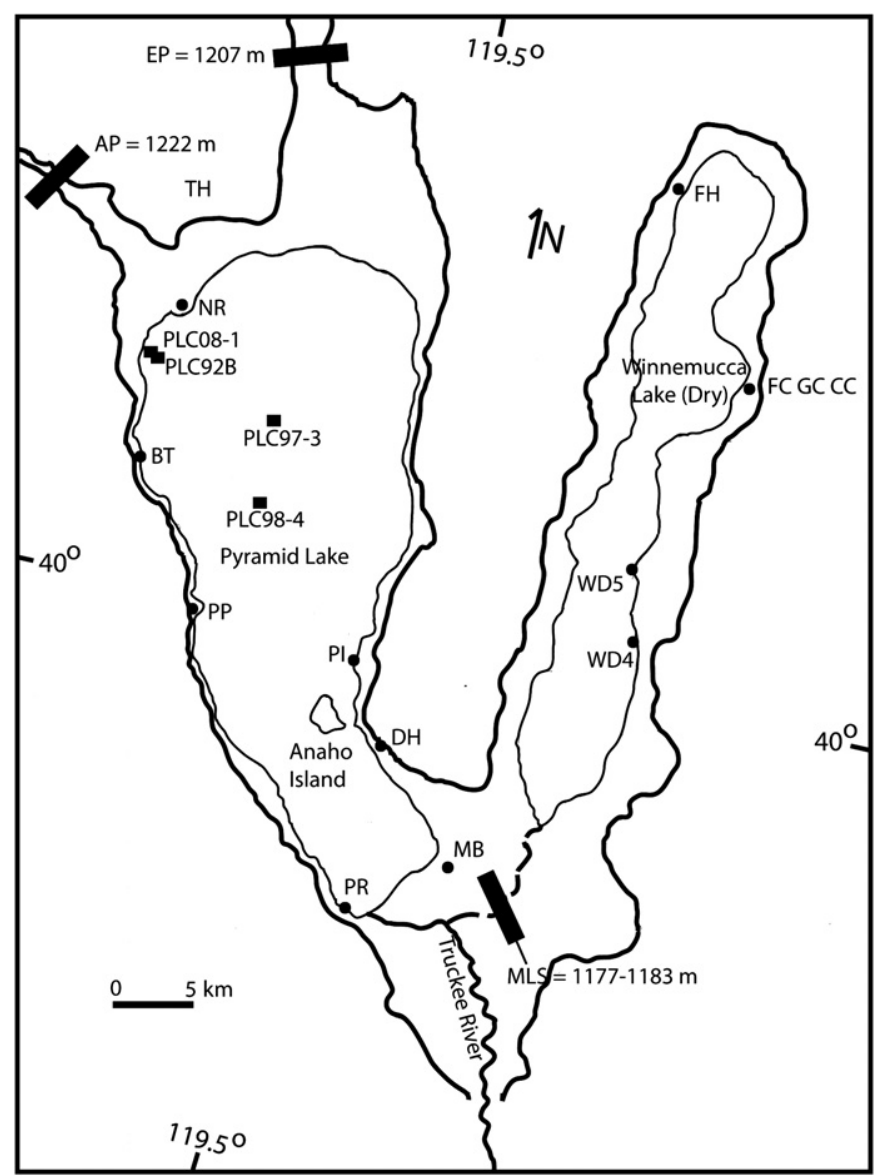

Fig. 3. Pyramid Lake and Winnemucca Lake basin site map. AP, EP, and MLS refer to the Astor Pass, Emerson Pass, and Mud Lake Slough spill points (sills). TH, NR, BT, PP, PI, DH, PR, MB refer, respectively, to the Terraced Hills, Needles Rocks, Blanc Tetons, Pelican Point, Pyramid Island, Doghead Rock, Popcorn Rock, and Marble Bluff tufa localities. FH, FC, GC, and CC refer to Falcon Hill, Fishbone Cave, Guano Cave, and Crypt Cave localities in the Winnemucca Lake basin. Tufa localities WD5 and WD4 in the Winnemucca Lake basin are only approximately located.

time based on the GISP2 chronology. A detailed explanation of the use of PSV to correlate lake-based climate records to the Greenland GISP2 ice-core $\delta^{18} \mathrm{O}$ record is discussed and illustrated in Section 5.1 (Figs. 3-5 and Supplementary Figs. 1-5) of Benson et al. (2011). The PSV data sets determined on core PLC08-1 will be included in a forthcoming paper which documents the existence of both the Mono Lake and Laschamp magnetic excursions in sediments of the Pyramid and Mono lake basins.

The PLC08-1 age model was applied to PLC92B via the depth-depth and depth-age correlations depicted in Fig. 4. Calibrated ${ }^{14} \mathrm{C}$ ages of the TOC fraction in 20 samples from PLC08-1 have been plotted along with the PSV-based ages for the same core in Fig. 5. The correlation between the PSV-based and calibrated ${ }^{14} \mathrm{C}$ ages is excellent except near the top of the core where the calibrated ${ }^{14} \mathrm{C}$ age is $\sim 1800 \mathrm{y}$ too old and between 8.8 and $6.5 \mathrm{~m}$ where the calibrated ${ }^{14} \mathrm{C}$ ages are $\sim 1500-3500$ y too young.

\subsubsection{PLC97-3}

Pyramid Lake core PLC97-3 was recovered in $\sim 94 \mathrm{~m}$ of water (Fig. 3) in 1997. A seismic survey of the lake had previously indicated that a sediment reflector was located a few meters below the sediment-water interface at the PLC97-3 site. The formal names of volcanic tephras are used when first referenced in this paper; however, their formal names are abbreviated when subsequently referenced both in the text and in Supplementary Table 8. The 

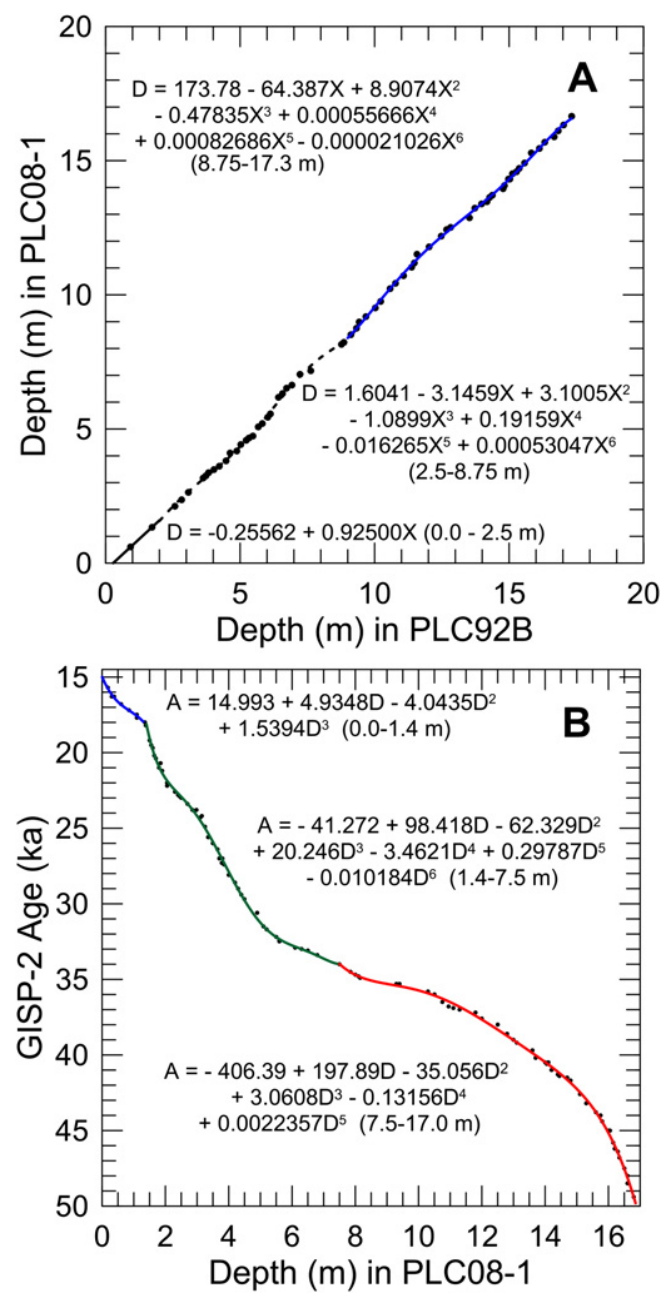

Fig. 4. A. Depth-Depth correlation between PLC08-1 and PLC92B created using the correlations shown in Supplementary Fig. 1 and the data of Supplementary Table 2. This allows PLC92B depths to be assigned equivalent PLC08-1 depths. B. GISP2 ages of 100 paleomagnetic secular variation (PSV) features in PLC08-1. The age model shown here can be transferred to PLC92B using the correlations shown in Fig. 4A.

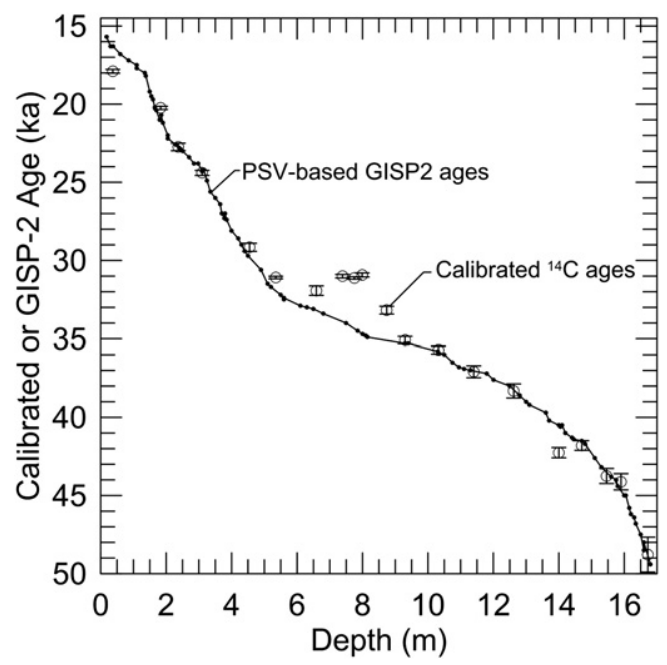

Fig. 5. PSV-based GISP2 and calibrated ${ }^{14} \mathrm{C}$ ages for PLC08-1.
Tsoyowata tephra (7.85 $\pm 0.02 \mathrm{ka}$, Sarna-Wojcicki et al., 1991) was found $1.74 \mathrm{~m}$ below the top of core PLC97-3 in faulted sediments that overlie a 22-cm-thick sandy unit (Fig. 6). An erosional contact between the sandy unit and a highly burrowed sandy mud occurs at $1.85 \mathrm{~m}$, and another sharp erosional contact marks the boundary at $1.95 \mathrm{~m}$ between overlying ostracode-rich sand and a $1.05-\mathrm{m}$ thick laminated unit. The seismic reflector is believed to be associated with the $1.95-\mathrm{m}$ erosional contact.

Given evidence of shallow-water conditions and erosive activity above $1.95 \mathrm{~m}$, PLC97-3 was sampled starting at the top of the laminated unit. Continuous 1 -cm-thick samples were taken from the bottom $2.43 \mathrm{~m}$ of sediment core. Parts of the core, which contain turbidites and slumped sediments, were subtracted from the core and its length readjusted to $4.00 \mathrm{~m}$.

Each sample was combined with deionized water, shaken, and centrifuged for $15 \mathrm{~min}$ at 20,000 rpm using a Sorval Superspeed RC2B. ${ }^{1}$ After centrifugation, the conductivity of the supernatant was measured and the supernatant discarded. This procedure was repeated until the specific conductivity of the supernatant was $<3$ times the conductivity of Boulder, Colorado, tap water. Samples were then freeze-dried and homogenized. Values of TIC were determined at the USGS Boulder Laboratory using a UIC Model 5012 carbon dioxide coulometer (Supplementary Table 3). Samples for isotopic analysis were pre-treated with bleach to remove organic matter and their TIC fraction dissolved in $100 \% \mathrm{H}_{3} \mathrm{PO}_{4}$ at $90{ }^{\circ} \mathrm{C}$ in a Multiprep device. Isotopic analyses $\left(\delta^{18} \mathrm{O}\right.$ and $\left.\delta^{13} \mathrm{C}\right)$ were made on the resulting $\mathrm{CO}_{2}$ (gas) using a Micromass Optima mass spectrometer at the USGS Denver Laboratory under the supervision of Robert Rye. Several samples, between 2.32 and $2.04 \mathrm{~m}$ in PLC97-3, contained extremely small amounts of TIC, precluding isotopic analysis by the aforementioned method. Thirty samples from this interval were analyzed at the Institute of Arctic and Alpine Research (INSTAAR), under the supervision of Bruce Vaughn, with a VG Sira series II mass spectrometer using a double cold-finger technique and a common acid bath.

Age control for PLC97-3 is based on 11 AMS ${ }^{14} \mathrm{C}$ determinations performed at the Lawrence Livermore National Laboratory (LLNL) Center for Accelerator Mass Spectrometry (CAMS) on the TOC fraction of cored sediment. Raw and calibrated ${ }^{14} \mathrm{C}$ ages of PLC97-3 and PLC08-1 samples have been listed in Supplementary Table 4. Small aliquots of sediment $(20-50 \mathrm{mg})$ were rinsed several times in an ultrasonic bath with deionized water to remove salts and also with $0.1 \mathrm{~N} \mathrm{HCl}$ to remove soluble carbonate from the sediment. The samples were then dried at $50{ }^{\circ} \mathrm{C}$ in a vacuum oven. The procedure used for oxidation of bulk organic matter in pre-treated sediment and subsequent reduction of $\mathrm{CO}_{2}$ to filamentous graphite for AMS assay is described in Vogel et al. (1987). Calibration of ${ }^{14} \mathrm{C}$ values was done using CALIB 6.01 (Stuiver et al., 2005). Three of 11 calibrated ${ }^{14} \mathrm{C}$ ages of sediment samples from PLC97-3 are excessively old, indicating reworking of old carbon from sediments that were eroded during the fall from the Lahontan highstand (after $\sim 15.5 \mathrm{ka}$ ). The age model created using the calibrated ${ }^{14} \mathrm{C}$ ages excluded the three anomalous dates (Fig. 7).

\subsection{Sedimentological analyses}

Sedimentological descriptions of PLC97-3 and PLC08-1 were made using the following procedures. Core segments were split lengthwise and their surfaces cleaned with a straight razor. Smear slides were collected from PLC97-3 when changes in sedimentary fabric occurred and also at a variety of depths to investigate shifts in the mineralogical character of the sediment. The slides were

\footnotetext{
1 Use of trade, product, or company name within this paper does not constitute an endorsement by the U.S. Government.
} 

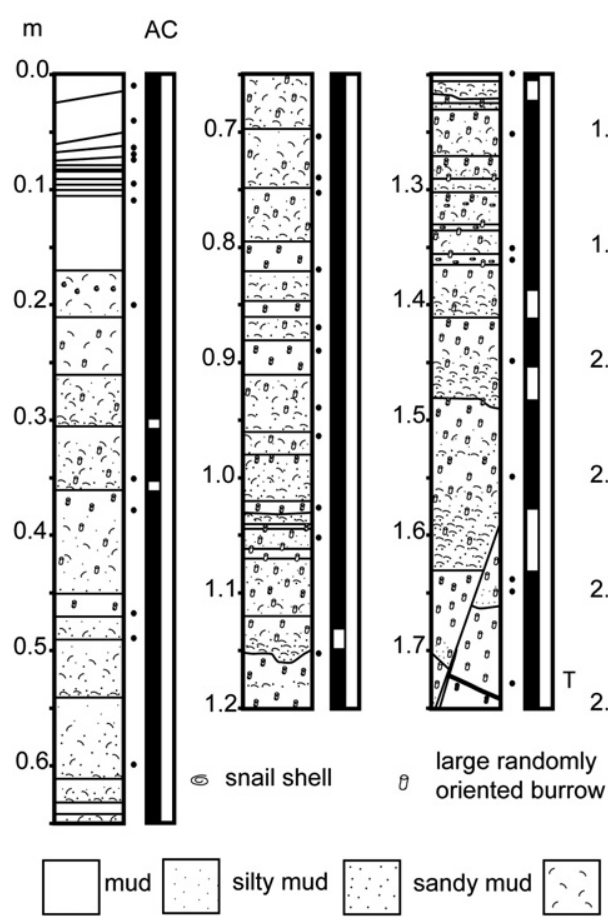

sandy mud

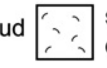
ostracodes

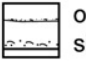
silt or sand

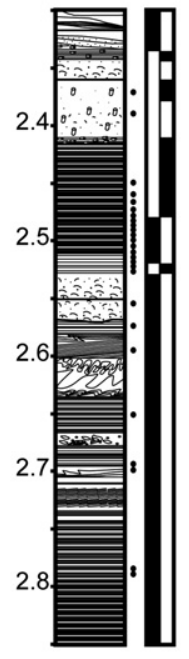

large randomly

o oriented burrow filled with sand
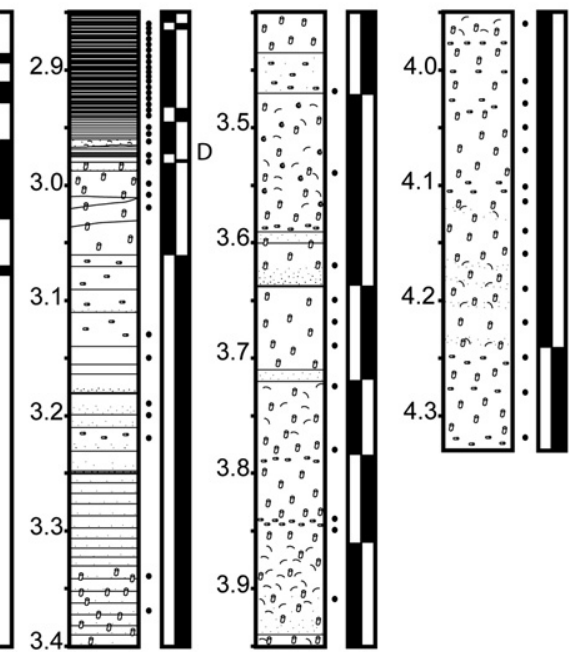

co small horizontally oriented burrow

- smear slide

\section{$A=$ aragonite $\mathrm{C}=$ calcite} $\mathrm{D}=$ dolomite $\mathrm{T}=$ tephra

Fig. 6. Core PLC97-3 stratigraphy and sedimentology.

examined with a petrographic microscope at $400 \times$ magnification. Sediment slabs imbedded with Spurr resin were recovered from the 3.00-1.95 m interval of PLC97-3 and were examined petrographically and with a scanning electron microscope in the backscatter mode. Slump and turbidite intervals were found to exist within the following depth intervals in PLC97-3: 2.98-2.97, 2.71-2.69, 2.68-2.67, 2.63-2.60, 2.57-2.53, 2.36-2.34, 2.33-2.32, 2.26-2.13, $2.04-2.00$, and $1.95-1.90 \mathrm{~m}$. These intervals were removed from the core description and the remaining depths sequentially renumbered before construction of the age model (Fig. 7). Uncorrected and corrected sample depths are listed in Supplementary Table 5.

\subsection{Preparation and electron microprobe analysis of tephra}

Tephra samples were prepared for analysis as received; no attempt was made to concentrate the glass component. The tephras

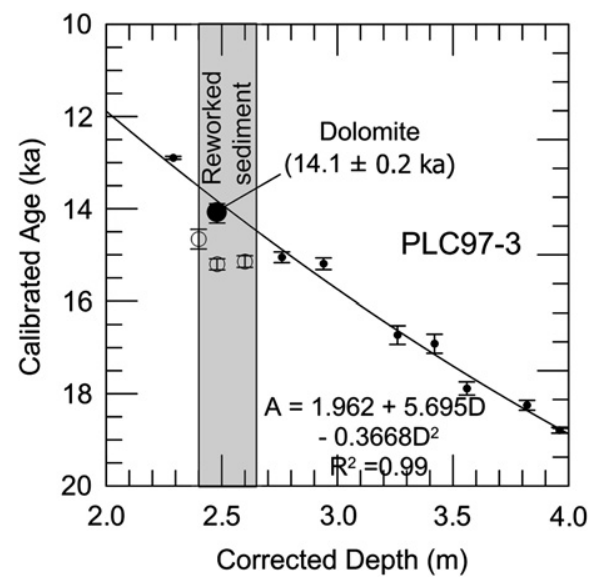

Fig. 7. Age model for core PLC97-3 based on calibrated ${ }^{14} \mathrm{C}$ ages of organic carbon material found outside the reworked sediment zone. The age of a dolomite layer in the core is based on an average of ${ }^{14} \mathrm{C}$ ages obtained on a thin layer of sucrosic dolomite that coats tufas at an elevation of $\sim 1160 \mathrm{~m}$. were placed in 8-mm-diameter rings (cells) fixed four to a petrographic side using epoxy. A few drops of epoxy were then added to each cell, thoroughly mixed, and allowed to cure. The cells were then trimmed using a low-speed diamond-wafer saw, ground on a lap to thin section thickness, polished using 1 micron diamond paste, and carbon coated.

The composition of the glass in the tephra was determined using the JEOL JXA-8500F electron microprobe in the GeoAnalytical Laboratory located in the School of Earth and Environmental Science at Washington State University. The analytical conditions were acceleration voltage $=15 \mathrm{kV}$; beam diameter $=8$ microns; beam current 12 nanoamps; and peak/background counting times (seconds) of 10/5 for $\mathrm{Mg}, \mathrm{Si}, \mathrm{Al}, \mathrm{K}, \mathrm{Ca}$, and $\mathrm{Ti} ; 20 / 5$ for $\mathrm{Na}, 40 / 10$ for $\mathrm{Fe}$ and $20 / 10$ for $\mathrm{Cl}$. The elemental calibration standards and details involving the calculation and use of the similarity coefficient (SC) as a tephra glass composition comparator are given in Foit et al.(2004).

\section{Interpretation of proxy-climate indicators}

\subsection{Mineralogical and chemical proxies of change in the hydrologic balance}

With respect to carbonate mineralogy, the transition from calcite to aragonite and from aragonite to dolomite is interpreted as reflecting a progressive increase in lake salinity and dissolved magnesium (Mg) concentration (Harvie and Weare, 1980). Low salinities occur when a hydrologically closed lake rapidly increases in size or when an increase in the rate of spill from the lake to an adjacent basin occurs. Salinity increases when a hydrologically closed lake decreases in size or when the rate of spill from a lake to an adjacent lake basin decreases.

In a relatively simple hydrologic system, TIC also can be used to estimate former lake size. In a hydrologically closed system, the relative concentration of TIC should decrease as lake size increases. This is because in many Great Basin surface-water systems the flux of siliciclastic material to a lake is an exponential function of discharge, 
whereas the flux of calcium (Ca) to the lake is a linear function of discharge (Benson et al., 2002). This assumes that the Ca entering the lake has a relatively brief residence time in the water body prior to its deposition as a carbonate mineral. In the case of a lake that overflows to an adjacent lake basin, the greater the overflow rate, the less the residence time of $\mathrm{Ca}$ in the overflowing lake, the less the amount of Ca available for precipitation from the overflowing lake.

However, the Lahontan Basin is not a simple hydrologic system: the amount of Ca entering the lake during pluvial conditions is also a function of the flux of Ca-rich geothermal waters. In addition, carbonates are deposited in both lake-bottom sediments and also in the form of massive "reefs" and tufa mounds. Therefore, a sediment-based TIC record does not yield an accurate history of overall carbonate production and storage. Lastly, the TIC records in PLC92B and PLC08-1 were also subject to dilution by glacial rock flour produced during the Tioga and earlier glacial advances (see, e.g., Benson et al., 1996b).

In this paper, the TOC record, a proxy for overall biologically productivity, is used to indicate the time of maximum Sierra Nevada alpine glaciation; the input of rock flour from these glaciers to Pyramid Lake via the Truckee River inhibited light penetration into the lake's surface waters, thereby reducing the rate of photosynthesis, resulting in the consequent reduction in abundance of diatoms and other algae. These organisms, which under non-glacial conditions contribute a major part of the organic matter reaching the lake bottom, were further diluted by the siliciclastic glacial rock flour that was deposited in lake-bottom sediments.

There are several factors that determine the $\delta^{18} \mathrm{O}$ value of carbonate deposited from lake water; however, the most important factors are the $\delta^{18} \mathrm{O}$ value of river discharge entering the lake and the $\delta^{18} \mathrm{O}$ value of water vapor exiting the lake's surface. In general, the lake at hydrologic and isotopic steady state will have an $\delta^{18} \mathrm{O}$ value equal to the $\delta^{18} \mathrm{O}$ value of river discharge minus the $\delta^{18} \mathrm{O}$ value of isotopically fractionated water vapor. If the volume of discharge exceeds the volume of evaporated water (rising lake level) the $\delta^{18} \mathrm{O}$ value of lake water will be less than the steady state value and vice versa. Lake-water $\delta^{18} \mathrm{O}$ values also will decrease with increasing overflow to an adjacent lake basin because evaporation has less time to fractionate the oxygen isotopes in the overflowing lake basin. For a detailed discussion of this topic, the reader is referred to Benson and Paillet (2002).

\subsection{Sedimentological indicators of lake depth and environment}

Burrowing style often reflects the oxidation or chemical state of lake water and lake-bottom sediments. Most burrowing organisms cannot exist in an anoxic environment. When both bottom-sediment pore fluids and bottom water become oxygen depleted, sediment laminae remain intact. If the sediment pore fluids are anoxic but the bottom water is oxic, burrowing organisms may persist on the sediment-water interface and create horizontal burrows. If both sediment pore fluids and bottom water are relatively oxygen rich, burrowing organisms may penetrate the sediment forming randomly oriented burrows. In some cases, burrowing may be sufficiently intense to produce massive sediment that lacks bedding planes. It should be noted that increases in lake salinity or toxic metals may also inhibit the existence of burrowing organisms. The reworking of fine-grained organic material from subaerial and shallow-water sediments during a fall in lake level may also render lake-bottom pore fluids and lake-bottom water anoxic.

In the following, a distinction is made between the terms "regular" and "irregular" laminae. These terms refer to the style of laminae stacking. Regular laminae are essentially stacks of layers that are similar in size and composition or that change in a systematic manner. Irregular laminae are stacks of layers with differing sizes or compositions. Regular laminae tend to form in deep water where the core site is located far from sources of sediment input such as near-shore and deltaic areas. However, if annual sediment input is relatively constant or very low, e.g., during low flows that occur during droughts, then regular laminae also may form in relatively shallow-water environments. Irregular laminae occur in relatively shallow-water environments where conditions of sediment deposition frequently vary. Thick irregular laminae usually form in shallow water where wave activity may partially remove some of the sediment and redeposit it as a thicker layer and where bioturbation may homogenize several sediment layers.

Contrary to the model presented by Smoot and Benson (1998), the presence of laminae does not necessarily indicate deep water. However, thick sequences of sub-millimeter laminae require water depths that exceed the depth at which wave energy capable of suspending silt and clay-sized sediment, unless organic mats have bound the sediment surface.

Ostracode-rich mud commonly contains beds and lenses of sandsized ostracodes. Burrows are indicated by ovate, shell-rich cross sections within mud and by ovate mud cross sections within shell sands. Many shell sands also contain siliciclastic sand grains. The ungraded beds of siliciclastic sand and ostracodes indicate concentration by storm-forced wave action. In shallow-water environments, relatively low wind velocities can produce waves capable of moving coarse sediment. During storms, wave activity can produce oscillatory ripples or it may simply concentrate coarse sediment by winnowing silt and clay into suspension. Using the wind-fetch relationships for deep-water Airy waves determined by the Army Corp of Engineers (see Johnson, 1980; Rowan et al., 1992) and the geometry of the Lahontan Basin, the maximum depth that a wind-induced wave can transport silt-sized sediment $(23 \mu)$ at the PLC08- 1 core site is $\sim 22 \mathrm{~m}$, and the maximum possible depth from which very fine sand $(0.02 \mathrm{~mm})$ can be transported is $\sim 16 \mathrm{~m}$. Therefore, the ostracode-rich mud facies in PLC08-1 and PLC92B is considered an indicator of shallow-water conditions.

Increased burrowing, leading to decreased bedding, indicates a deeper-water environment where burrowers have more time to rework beds between infrequent intense storms. A transitional bedding type consists of layers of silty mud containing fine-sandsized ostracodes. The presence of this bedding type indicates relatively deep-water conditions where waves move only silt-sized siliciclastic material together with small ostracode valves.

The simple sediment deposition model assumes that sedimentary textures will evolve as a lake changes size. A deep or overflowing lake will not be biologically productive and, therefore, will be oxygen rich, allowing the formation of randomly spaced burrows. When the core site is in relatively deep water, sediments will be fine-grained, unbedded, and sand and ostracode layers will be absent. If the lake is very large when it starts falling, paper thin laminae (microlaminae) will be preserved. Furthermore, if a density-stratified lake receives additional fresh water, its stratified state may result in the preservation of sediment laminae. As water depth decreases, the lake becomes saline, biologically productive, and may become density-stratified, resulting in sediment and bottom water anoxia. The sediment will initially be regularly laminated, and as the lake continues to fall, the sediment will become characterized by irregular laminae.

\section{Results}

\subsection{Sedimentary record}

Sediment ages in this section are usually reported to two decimal places. The data are not that accurate but they are that precise. 


\subsubsection{Core PLCO8-1}

A schematic sedimentology of PLC08-1 is depicted in Fig. 8 and a detailed description of core PLC08- 1 sedimentary fabric is listed in Supplementary Table 6 . PLC08- 1 sediments can be divided into three major categories: (1) unbedded muds with abundant burrows, (2) laminated muds, and (3) ostracode-rich muds which contain sand layers composed of siliciclastic grains and ostracodes. The term "mud" refers to sediment primarily composed of claysized material with some silt and (or) sand.

Between the base and $5.32 \mathrm{~m}(48.00-31.92 \mathrm{ka})$ of PLC08-1 the sediment is characterized by alternations of laminated mud and mud containing ostracode sand lenses (Fig. 8). These alternations are interpreted as indications of rising and falling lake levels, without prolonged periods of overflow. The presence of ostracode sand lenses, indicating wave reworking, suggest very shallowwater conditions between 16.85 and $16.83 \mathrm{~m}$ (49.49-49.35 ka), $16.57-15.98 \mathrm{~m}$ (47.68-44.86 ka), $14.60-14.50 \mathrm{~m}$ (41.30-41.13 ka), 13.47-13.09 m (39.56-39.03 ka), 12.03-11.68 m (37.61-37.18 ka), and $9.62-9.52 \mathrm{~m}(35.49-35.45 \mathrm{ka})$. A simple relationship between sedimentary structures and depth does not exist. Supplementary Appendix 1 discusses this issue in detail. The presence of microlaminae between 15.57 and $15.29 \mathrm{~m}$

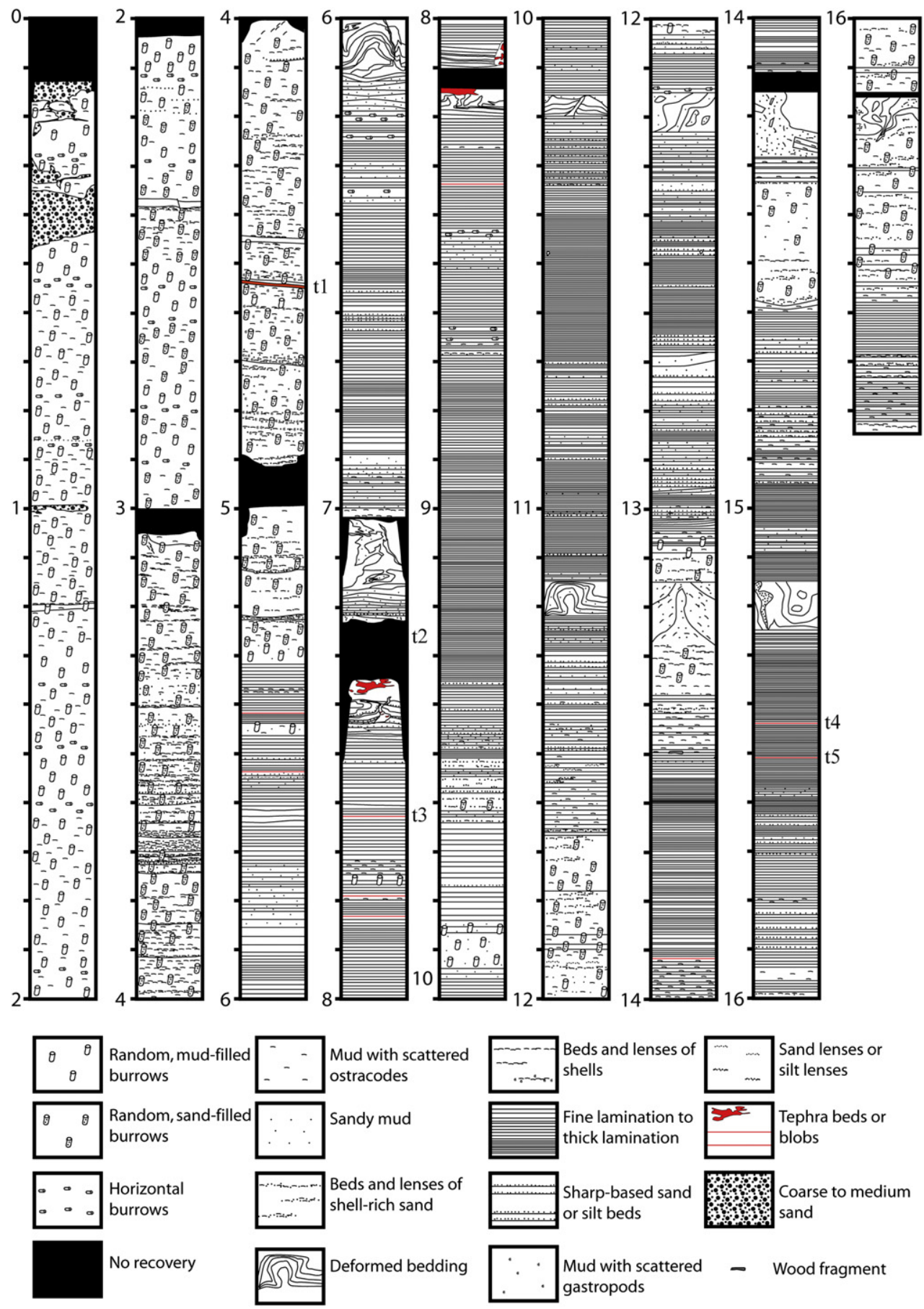

Fig. 8. Core PLC08-1stratigraphy and sedimentology. Tephras t1, t2, t3, and t4/t5 refer respectively to the Trego Hot Springs, the Wono, the Carson Sink/Wilson Creek Ash 15 , and Marble Bluff tephras. 
(43.48-42.73 ka), 13.68-13.62 m (39.86-39.78 ka), 12.64-12.49 m $(38.42-38.21 \mathrm{ka}), \quad 10.70-10.40 \mathrm{~m}$ (36.17-35.93 ka), and 9.35-8.97 m (35.39-35.25 ka) suggests very deep-water conditions. Some rising lake levels are indicated by increased siliciclastic sediment content and bioturbation between 15.94 and $14.57 \mathrm{~m}$ (44.71-41.25 ka), 13.08-12.62 m (39.02-38.39 ka), 11.50-10.70 m $(36.97-36.17 \mathrm{ka})$, and $9.94-9.34 \mathrm{~m}(35.65-35.38 \mathrm{ka})$. The $5.23-3.09 \mathrm{~m}(31.75-25.47 \mathrm{ka})$ sediment interval is interpreted to indicate very shallow-water conditions, given an abundance of well-sorted wave-reworked ostracode sand lenses. Bioturbated intervals within this interval indicate rising lake levels at $5.32 \mathrm{~m}$ (31.92 ka), $5.05 \mathrm{~m}$ (31.37 ka), $4.80 \mathrm{~m}$ (30.72 ka), $4.14 \mathrm{~m}$ (28.44 ka), and $3.79 \mathrm{~m}(27.04 \mathrm{ka})$. From $3.0 \mathrm{~m}$ (24.19 ka) depth to the core top (14.99 ka), the sediment is dominated by heavily bioturbated mud. This is interpreted as indicating predominately spilling conditions.

In PLC08-1, laminated intervals represent times of relatively higher sedimentation; however, the highest sedimentation rates are associated with declining lake levels. Thicker sedimentary units are formed during decreases as opposed to increases in lake level. Sediment layers formed during rising lake levels are typically thin $(<1 \mathrm{~cm})$. Isotopic analyses of 4 -cm-thick sediment samples incorporate both the low $\delta^{18} \mathrm{O}$ values associated with rising lake levels and the higher $\delta^{18} \mathrm{O}$ values associated with declining lake levels. This process is suggested to account for the low $\delta^{18} \mathrm{O}$ variability observed in several core intervals (see Supplementary Table 6). The lowest $\delta^{18} \mathrm{O}$ values are associated with green clays that are either interbedded with or directly overlie muds that contain ostracode sand layers. This suggests that green clays are deposited during periods of lake level rise with little or no carbonate precipitation. In several intervals, the green clays are overlain by laminated, carbonate-rich muds that grade to laminated muds. Sediment $\delta^{18} \mathrm{O}$ values increase throughout this transition in sediment fabric. The changes in sediment fabric and $\delta^{18} \mathrm{O}$ are interpreted to indicate a hydrologic transition from a spilling lake to a hydrologically closed lake that filled multiple basins and fluctuated above the connecting spill elevation(s).

It appears that carbonate-poor sediment deposited during the influx of glacial flour had a lower rate of sedimentation than carbonate-rich sediment that contains little clastic material. This unusual observation can be explained by sediment focusing which occurred during declining lake levels.

Whereas the PLC08- $1 \delta^{18} \mathrm{O}$ record reliably indicates the direction of lake level change (up or down), the $\delta^{18} \mathrm{O}$ record does not accurately indicate the magnitude of change in lake size. For a given volume of water input to the lake, the largest shifts in $\delta^{18} \mathrm{O}$ occur when the lake is small. In addition, the $4-\mathrm{cm}$ sediment sampling increment tends to overemphasize the presence of thick, isotopically heavy, sediment deposited during lake-level regressions over isotopically light, thin layers of sediment that formed during lakelevel transgressions.

The sedimentary record of PLC08- 1 indicates multiple episodes of lake-level rise above the Emerson Pass sill $(1207 \mathrm{~m})$ prior to deposition of the Trego Hot Springs (tephra) Bed (deposited $29.9 \mathrm{ka}$ ). Smoot (1993) recognized seven lake-level rises that flooded the Truckee River Canyon. Absolute dating of these units in not possible at this time; however, lacustrine unit L3 formed prior to the deposition of the PLC08- 1 sedimentary sequence and lacustrine units L4 and L5 are older than the Wono (tephra) Bed. Lacustrine unit L6 probably formed during the lake-level rise that occurred shortly after deposition of the Trego Hot Springs Bed and lacustrine unit L7 probably formed during the Lahontan highstand.

\subsubsection{Core PLC92B}

In core PLC92B, burrowed beds containing ostracodes are frequently aragonitic and the ostracode-poor beds are mostly calcitic (data not shown). These relationships suggest that sediments, which contain horizontal burrows were deposited as the lake rose, whereas randomly burrowed sediments, rich in ostracodes, were deposited as the lake fell. Given this argument, there are a number of asymmetric successions comprised of a thin rising lake sediment sequence overlain by a thicker falling lake sediment sequence. These occur at 2.91-2.80 $\mathrm{m}(23.93-23.64 \mathrm{ka})$, $2.80-2.62 \mathrm{~m}$ (23.64-23.20 ka), 2.62-2.56 m (23.20-23.06 ka), 2.56-2.30 m (23.06-22.48 ka), 2.30-2.12 m (22.48-22.05 ka), 2.12-1.95 m (22.05-21.54 ka), 1.95-1.50 m (21.54-19.06 ka), $1.50-1.36 \mathrm{~m}$ (19.06-18.10 ka), $1.36-0.97 \mathrm{~m}$ (18.10-17.38 ka), and $0.55-0.29 \mathrm{~m}(16.74-16.12 \mathrm{ka})$. There is a suggestion of another asymmetric sedimentary succession beginning at $0.29 \mathrm{~m}(16.12 \mathrm{ka})$ and which indicates a decline in lake level towards core top. The upper $45 \mathrm{~cm}$ of core is intruded by shell-rich sand and there is another intrusive layer at $1.0 \mathrm{~m}(17.42 \mathrm{ka})$.

Deep water deposits in PLC08-1 and PCL92B are generally correlatable; however, synchronous shallow-water deposits in both cores may differ considerably due to the fact that PLC92B was recovered in somewhat deeper water than PLC08-1. For example, there should be more sand layers in PLC08-1 than in PLC92B. In addition, the presence of carbonate (TIC) maxima in the sediment cores may not occur at the same times during low lake levels because accumulations of TIC-rich ostracode lenses may not occur synchronously at the two core sites.

\subsubsection{Core PLC97-3}

A schematic sedimentology of PLC97-3 is depicted in Fig. 6. Given that PLC97-3 was recovered in order to extend the PLC08-1 record forward in time, the focus is on the $3.47-$ to- $1.95-\mathrm{m}$ (16.2-11.7 ka) interval in PLC97-3. Table 1 lists the depths and ages of sedimentary units and carbonate mineral zones in PLC97-3. Uncorrected sediment depths keyed to Fig. 6 will be referenced throughout this paper. Supplementary Table 5 can be used to obtain the corrected depth (slumped sediment and turbidites removed) from a given uncorrected depth and Fig. 7 can be used to obtain sediment age from corrected sediment depth.

The interval between 3.47 and $3.06 \mathrm{~m}$ (16.2-14.8 ka) consists primarily of a carbonate-poor, silty mud which contains micronsized anhedral calcite crystals. The dominant presence of calcite throughout this interval indicates the existence of a large-volume lake that probably was deepening over time. Layers of silt and sand within this interval are poorly sorted and may represent "dropstones" from the lake's ice-covered surface. The absence of burrows between 3.38 and $3.13 \mathrm{~m}$ (15.9-15.1 ka) indicates the presence of anoxic bottom water and sediment, which implies the existence of a density-stratified lake.

Carbonate-rich aragonite mud with numerous, randomly oriented burrows characterize the $3.06-2.97 \mathrm{~m}(14.8-14.5 \mathrm{ka})$ interval. The presence of aragonite within this interval suggests that lake size was decreasing and the presence of burrows suggests that lake water was nearly or completed saturated with oxygen and no longer density stratified. Dolomite is found between 2.97 and $2.96 \mathrm{~m}$ and indicates the former presence of a shallow, saline, Mgrich water body at $\sim 14.4 \mathrm{ka}$.

Between 2.96 and $1.95 \mathrm{~m}(14.4-11.7 \mathrm{ka})$, the sediments are frequently laminated and unburrowed. Finely laminated units within this interval consist of organic-rich clays, containing pelagic diatoms that alternate with subhedral-to-anhedral micron-size calcite crystals. Thicker laminae in this interval consist of clay-rich layers, which contain small pelagic diatoms that alternate with the aragonite-rich layers, which contain a mixture of pelagic and benthic diatoms. Many of the non-laminated sedimentary units within this interval consist of reworked, slumped sediment and turbidites; e.g., the 2.65-2.40 $\mathrm{m}$ interval contains old reworked 
Table 1

Depths and ages of sedimentary units and mineral zones in PLC97-3.

\begin{tabular}{|c|c|c|c|c|c|c|c|}
\hline \multirow[t]{2}{*}{ Sedimentary units } & \multicolumn{2}{|c|}{ Uncorrected D (m) } & \multicolumn{2}{|c|}{ Corrected D (m) } & \multicolumn{2}{|l|}{ Age (ka) } & \multirow[t]{2}{*}{ Interpretation } \\
\hline & Bottom & Top & Bottom & Top & Bottom & Top & \\
\hline Finely laminated seds. & 2.97 & 1.95 & 2.66 & 1.95 & 14.51 & 11.67 & Oscillating lake level with sediment reworking \\
\hline Silty mud & 3.47 & 2.97 & 3.14 & 2.66 & 16.23 & 14.51 & Deep lake \\
\hline Ostracode-rich aragonite mud & $<1.95$ & & $<1.95$ & & $<11.67$ & & Relatively shallow lake \\
\hline $\begin{array}{l}\text { Ostracode-rich aragonite mud and } \\
\text { carbonate-poor calcite mud }\end{array}$ & 3.85 & 3.47 & 3.52 & 3.14 & 17.46 & 16.23 & Oscillating lake level \\
\hline Reworked ${ }^{14} \mathrm{C}$ zone & & & 2.65 & 2.40 & 14.48 & 13.52 & Falling lake \\
\hline Rice-grain calcite & \multicolumn{2}{|c|}{2.86} & \multicolumn{2}{|c|}{2.55} & \multicolumn{2}{|c|}{14.10} & Relatively deep stratified lake \\
\hline Rice-grain calcite & \multicolumn{2}{|c|}{2.95} & \multicolumn{2}{|c|}{2.64} & \multicolumn{2}{|c|}{14.44} & Relatively deep stratified lake \\
\hline $\begin{array}{l}\text { Burrow-free silty mud } \\
\text { Carbonate Mineralogy }\end{array}$ & 3.38 & 3.13 & 3.05 & 2.81 & 15.92 & 15.07 & Stratified lake \\
\hline Calcite & 4.32 & 4.25 & 4.00 & 3.92 & 18.87 & 18.66 & Deep overflowing lake \\
\hline Aragonite & 4.25 & 3.85 & 3.92 & 3.52 & 18.66 & 17.46 & Relatively deep hydrologically closed lake \\
\hline Calcite/Aragonite & 3.85 & 3.47 & 3.52 & 3.14 & 17.46 & 16.23 & Oscillating lake level/spill rate \\
\hline Calcite & 3.47 & 3.06 & 3.14 & 2.73 & 16.23 & 14.78 & Deep lake \\
\hline Aragonite & 3.06 & 2.97 & 2.73 & 2.66 & 14.78 & 14.52 & Fall from highstand \\
\hline Dolomite & 2.97 & 2.96 & 2.66 & 2.65 & 14.52 & 14.48 & Very shallow lake \\
\hline Aragonite & 2.96 & 2.47 & 2.65 & 2.27 & 14.48 & 13.00 & Shallow lake \\
\hline Calcite & 2.47 & 2.41 & 2.27 & 2.20 & 13.00 & 12.72 & Rising lake \\
\hline Aragonite & 2.41 & 2.16 & 2.20 & 2.09 & 12.72 & 12.26 & Oscillating lake level with sediment reworking \\
\hline Calcite & 2.16 & 1.97 & 2.09 & 1.97 & 12.26 & 11.76 & Relatively deep lake \\
\hline Aragonite & 1.97 & 1.95 & 1.97 & 1.95 & 11.76 & 11.67 & Falling lake \\
\hline
\end{tabular}

Corrected depths indicate that sediment slumps and turbidites have been removed from the stratigraphic section.

carbon that altered the depositional $\left({ }^{14} \mathrm{C}\right)$ age of the sediment and that also introduced carbonate minerals whose $\delta^{18} \mathrm{O}$ and $\delta^{13} \mathrm{C}$ values are not representative of existing lake water. It is suspected that old fine-grained organic carbon has been focused into the PLC97-3 core site along with clay-size sediment. The lack of burrowing within the autochthonous sediment fraction suggests that sediments and bottom waters were anoxic, probably as a result of the addition of substantial quantities of easily eroded allochthonous organic carbon that had originally been deposited in sediments at higher elevations within the basin. Oxygen deprivation of bottom water also may have been exacerbated by periods of lake stratification (meromixis).

The 2.96-2.47-m (14.5-13.0 ka) interval contains aragonite, suggesting the existence of a relatively shallow closed-basin lake. Between 2.47 and $2.41 \mathrm{~m}(13.0-12.7 \mathrm{ka})$, calcite was the dominant carbonate precipitate, which indicates that the lake rose and possibly spilled to an adjacent basin during this time interval. Aragonite was deposited in the unreworked part of the $2.41-2.16 \mathrm{~m}$ $(12.7-12.3 \mathrm{ka})$ sedimentary interval, indicating the lake was hydrologically closed. Calcite is found between 2.16 and $1.97 \mathrm{~m}$ (12.3-11.8 ka), suggesting the presence of a relatively deep, rising or spilling lake in the Pyramid Lake basin. The presence of aragonite between 1.97 and $1.95 \mathrm{~m}$ (11.8-11.7 ka) indicates a declining lake level. The sharpness of the ostracode-mud/laminated-mud contact at $1.95 \mathrm{~m}$ implies that some sediment from above the $1.95-\mathrm{m}$ contact was eroded from the core site and focused into deeper parts of the basin, possibly during the middle Holocene megadrought (Benson et al., 2002).

\subsection{The tufa-based record of lake-level change}

The elevations, $\delta^{18} \mathrm{O}$ values, and ${ }^{14} \mathrm{C}$ ages (calibrated and uncalibrated) of subaerially exposed carbonate deposits (tufas) from the Pyramid and Winnemucca lake basins are listed in Supplementary Table 7 (data from Benson et al., 1992, 1995, 1996a). Also listed in the Supplementary Table 7 are ${ }^{14} \mathrm{C}$ and calibrated ages of several organic samples from Winnemucca Lake basin caves and rock shelters (Fig. 9) (data from Benson and Thompson, 1987). Most of the organic samples were sealed within crystallized packrat urine (amberat); therefore, these samples define an upper lake- level limit whereas the carbonate (tufa) samples define a lower lake-level limit.

\subsubsection{Tufa forms}

There are a variety of tufa forms found within the Pyramid Lake and Winnemucca Lake basins, which, for simplicity, can be lumped into the following categories: tubular, thinolitic, dendritic, dense, dolomitic, and porous encrusting (popcorn-like) tufa. The $<1-\mathrm{cm}-$ thick popcorn-like tufas are confined to the Holocene period, which is outside the time range of this study. Fig. 10 shows examples of the other tufa forms deposited in the Pyramid Lake basin. The tubular tufas were formed from springs that penetrated the basin bottom. The tubes formed from the outside inward in a manner similar to the genesis of hydrothermal-vent "black smokers" found straddling the mid-ocean ridge (see, e.g., Lonsdale, 1977). Tubes can be found at the base of all tufa mounds (e.g., Popcorn Rocks, Pelican Point, Blanc Tetons, and the Needles Rocks) located along the present shore of Pyramid Lake at an elevation of 1160-1190 m and within the cores of mounds such as Doghead Rock (base elevation $\sim 1220 \mathrm{~m}$ ) (Fig. 3).

At low elevations (1160-1190 m), the tufa order of formation was: tubular, old-dendritic, young-thinolitic, young-thinolitic/ young-dendritic transition, sucrosic dolomite, dense laminated calcite, and porous encrusting (Fig. 10B and C and Fig. 11). Youngthinolitic tufa disappears above an elevation of $\sim 1220 \mathrm{~m}$; e.g., Doghead Rock, whose base is at 1220 m, lacks young-thinolitic tufa and contains a complex of small-diameter tubes that are surrounded by dendritic pillow-form tufas (Fig. 10D). At even higher elevations (e.g., Marble Bluff at $1251 \mathrm{~m}$, Fig. 3), tubes are completely absent and reef-like tufas, containing dendritic pillow-forms, dominate the landscape (Fig. 10E). After all lakes in the Lahontan Basin coalesced above $1308 \mathrm{~m}$, only a relatively thin dense layer of carbonate was deposited (Fig. 10F).

\subsubsection{Tufa-based lake-level envelope}

Calibrated ages and elevations of the tufa and organic samples listed in Supplementary Table 7 have been used to create a lakelevel envelope for the Pyramid and Winnemucca lake basins for the period 45 to $\sim 10 \mathrm{ka}$ (Fig. 12A). Because many of the tufa forms, such as the mounds that surround the shores of Pyramid Lake, 


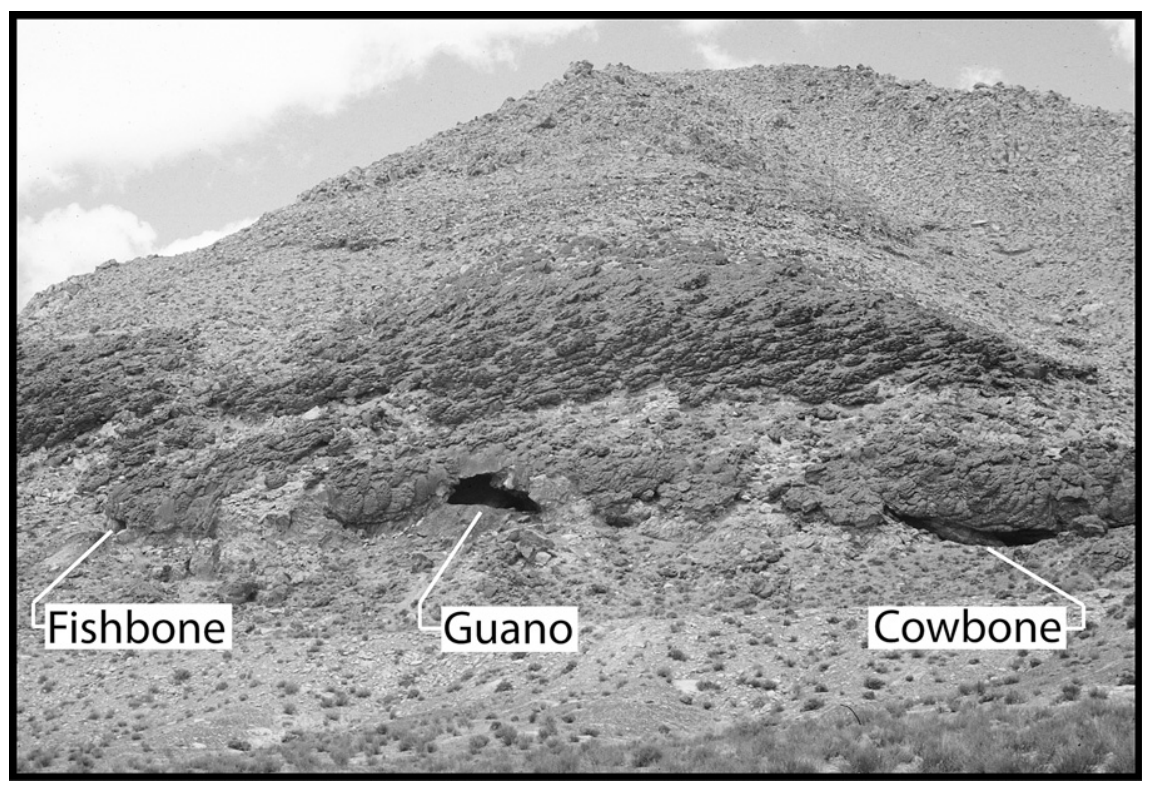

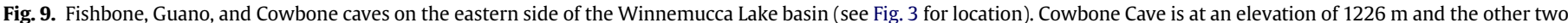
caves are at elevations of $\sim 1231 \mathrm{~m}$ (Alvin McLane, personal communication, 2006).

formed in a variety of water depths, and because the exact depth of formation of most of the other tufa forms (other than beachrock) is not known, a lake-level "envelope" was drawn above the maximum elevations of the dated tufas. The envelope was drawn below the elevation of the soil found in Astor Pass and below the depths of soluble organic samples found in the Winnemucca Lake Basin caves. In addition, the height of the lake during the Younger Dryas event was constrained by the elevation range of the wave-cut terrace exposed on Anaho Island (Fig. 12A). The spill point from Pyramid Lake to the Winnemucca Lake basin probably fell from 1183 to 1177 m during the Holocene (Benson, 1994b). Thus, lake levels and tufa deposition in the Pyramid Lake basin generally occurred at elevations below 1183 m during the Holocene. Many of the low-elevation (1177-1183 m) mounds were exposed to Holocene carbonate precipitation when not protected by a surrounding layer of sediment. Therefore, sampling and dating of many of the older tufa forms below $1183 \mathrm{~m}$ was not attempted, given the obvious presence of secondary carbonate that permeated the mounds at low elevations. Most of the ${ }^{14} \mathrm{C}$ dates obtained on lowelevation tufa forms were from uncontaminated tufas whose protective sediment had been removed by a lake-level oscillation that occurred during the mid-1980s (see Fig. 4 in Benson, 1994a). Thus, for the most part, tufa-based lake-level data for elevations between 1160 (the elevation of recent exposure) and $1183 \mathrm{~m}$ are lacking for the period 45-25 ka (Fig. 12A).

The tufa-based lake-level envelope (Fig. 12A) indicates that lake level in the Pyramid Lake basin may have been below the spill point $(1177-1183 \mathrm{~m})$ to the Winnemucca Lake basin much of the time prior to $27 \mathrm{ka}$. However, given the paucity of dates between 45 and $27 \mathrm{ka}$, it is probably safer to assume that Pyramid Lake did not exceed its spill elevation to the Smoke Creek-Black Rock Desert basin (Emerson Pass at 1207 m, Fig. 3) during this time period.

The lake-level envelope indicates an abrupt rise in level beginning at $25 \mathrm{ka}$. By $23.5 \mathrm{ka}$ the lake had reached its spill point to the Carson Desert basin (Darwin Pass sill at $1265 \mathrm{~m}$ ) and oscillated at or below that level until $\sim 19.5 \mathrm{ka}$. By about $18.7 \mathrm{ka}$, a soil formed on a chara-diatom deposit at Astor Pass (Fig. 13), indicating that the lake had receded below $1253 \mathrm{~m}$ (Supplementary Table 7, Fig. 3). The oscillation in lake level between 19.5 and $18 \mathrm{ka}$ is referred to as the Astor Pass Oscillation. By $18 \mathrm{ka}$, the lake was rising, and by $\sim 17 \mathrm{ka}$
Lake Lahontan had coalesced into a single water body with a surface elevation $>1308 \mathrm{~m}$. By $15.5 \mathrm{ka}$, the lake had reached its 1335-m highstand after which it fell rapidly, becoming saline, forming a thin layer of dolomite at $\sim 1160 \mathrm{~m}$ between 14.4 and $13.9 \mathrm{ka}$ (Supplementary Table 7, Fig. 10C). It is possible that Pyramid Lake was hydrologically closed and not spilling to the Winnemucca Lake basin during the latter time interval.

After $13.9 \mathrm{ka}$, a relatively thin $(<2 \mathrm{~cm})$ layer of dense calcite formed on the exposed dolomite layer, indicating a freshening of the lake due either to spill or to an increase in lake volume. Between 13.2 and $11.3 \mathrm{ka}$, a dense calcitic algal tufa was deposited at an elevation of $1205 \mathrm{~m}$ in the Winnemucca Lake basin (Supplementary Table 7). This indicates that lakes in the Pyramid and Winnemucca lake basins had coalesced and were spilling, at least intermittently, into the Smoke Creek-Black Rock Desert basin. Support for this comes from the presence of a 1207- to 1225-m wave-cut erosional terrace present on both Anaho Island and Marble Bluff (Figs. 3 and 14). The Anaho Island terrace consists of a lower relatively flat step that extends from 1207 to $1210 \mathrm{~m}$ and an upper erosional riser that extends from 1210 to $\sim 1225 \mathrm{~m}$. A lakelevel >1207 implies that lakes in the Pyramid Lake, Winnemucca Lake, and Smoke Creek-Black Rock Desert basins had coalesced. Tufas with dates between 11.3 and 10.2 ka were collected from an elevation range of $1159-1163 \mathrm{~m}$, suggesting the lake had fallen at least $45 \mathrm{~m}$ by $11.2 \mathrm{ka}$ (Supplementary Table 7 ).

\subsubsection{Tufa $\delta^{18} \mathrm{O}$ values}

The tufa $\delta^{18} \mathrm{O}$ data (Fig. 12B) confirm the rapid increase in lake volume which began $\sim 25 \mathrm{ka}$. During intermittent spill to the Carson Desert basin, between 23 and $19.5 \mathrm{ka}$, tufa isotopic values remained depressed. Two forms of tufas were deposited when the lake level exceeded $1308 \mathrm{~m}$ : dense tufa coatings above $1308 \mathrm{~m}$ and young-dendritic reef-like branching tufas below $1308 \mathrm{~m}$ (Fig. 12A) The high-elevation tufas possess significantly lower $\delta^{18} \mathrm{O}$ values $(27.0 \pm 0.2 \%)$ than the young-dendritic reef-like tufas at $1251 \mathrm{~m}$ $(28.5 \pm 0.8 \%), 1217-1221 \mathrm{~m}(28.2 \pm 0.2 \%)$, and $1160 \mathrm{~m}$ $(29.2 \pm 0.7 \%)$. The difference in $\delta^{18} \mathrm{O}$ values between highelevation dense tufas and the lower-elevation reef-like tufas implies that the lake became stratified sometime before the highstand was achieved. However, a $\delta^{18} \mathrm{O}$ biologic vital effect cannot be 

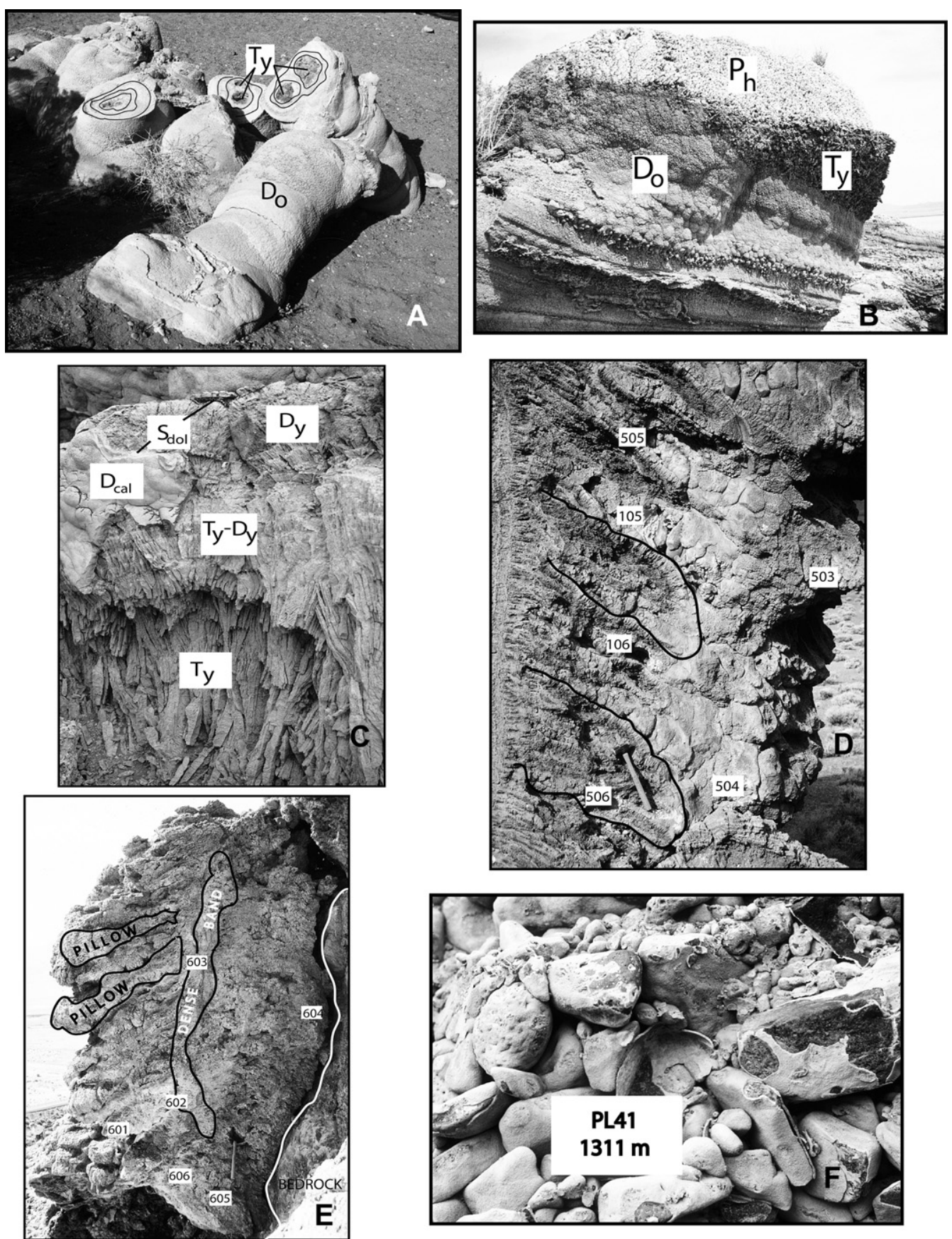

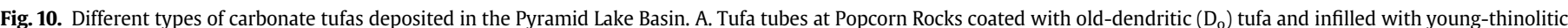

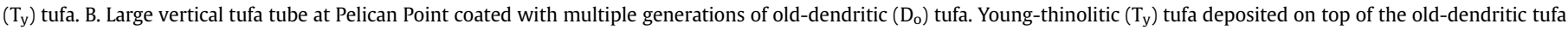

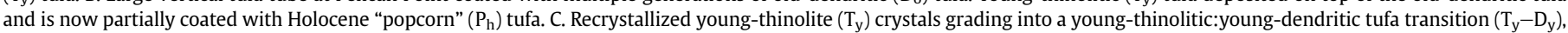

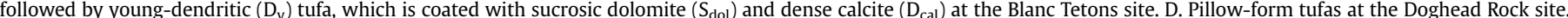

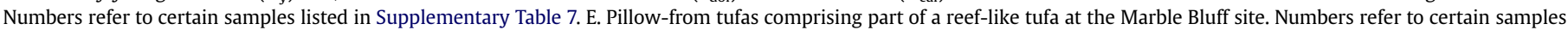
listed in Supplementary Table 7. F. Thin, dense tufa coating cobbles and gravel at the high-elevation Pipeline Canyon site located south of Pyramid Lake.

completely ruled out if the reef-like tufas formed organically. The extremely low dolomite $\delta^{18} \mathrm{O}$ values between 14.4 and $13.9 \mathrm{ka}$ support the existence of a shallow, saline, closed-basin at this time. Due to isotopic fractionation, dolomite values may be as much as $3 \%$ heavier than calcite precipitated from the same water (Aharon et al., 1977).

The isotopically depleted $\delta^{18} \mathrm{O}$ values $(<28.5 \%$ ) of some dense calcitic tufas deposited between 12.8 and 11.3 ka strongly support the existence of a deep lake in the western Lahontan Basin during this time interval. The spread in $\delta^{18} \mathrm{O}$ values within this time interval also suggests a great deal of variability in the hydrologic balance and (or) that the lake was intermittently stratified.

\subsection{The PLC92B $\delta^{18} \mathrm{O}$ record of change in the hydrologic balance of Lake Lahontan}

A smoothed (3-point running average) $\delta^{18} \mathrm{O}$ record from core PLC92B is shown in Fig. 12C. This continuous $\delta^{18} \mathrm{O}$ record of relative change in the hydrologic balance of Lake Lahontan indicates the following: (1) the rise to the Carson Desert spill point begins at 


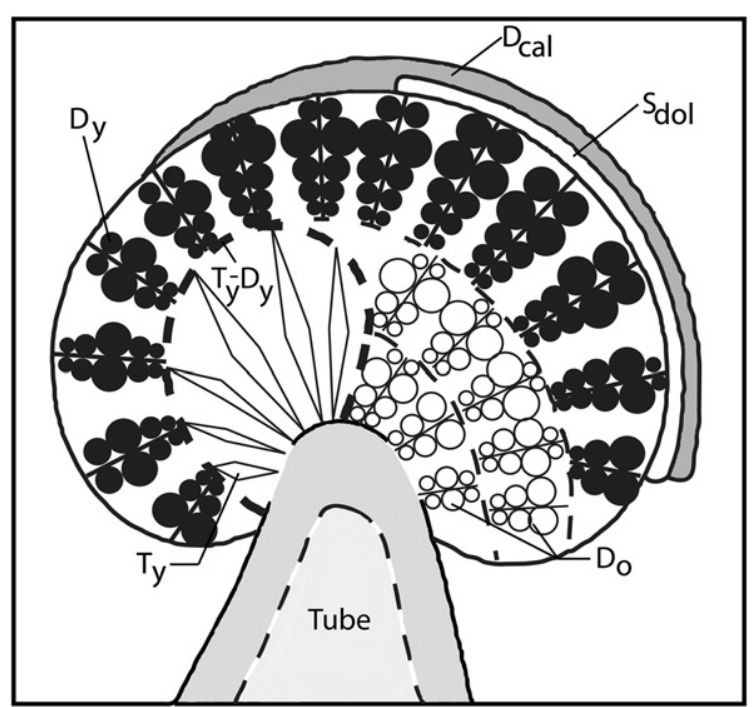

Fig. 11. Schematic of tufa deposition at low elevations in the Pyramid Lake basin. $D_{0}$, $T_{y}, T_{y}-D_{y}, D_{y}, S_{d o l}, D_{c a l}$ refer, respectively, to old-dendritic, young-thinolitic, olddendritic:young-thinolitic transitional, young-dendritic, sucrosic-dolomitic, and dense-calcitic tufas. Final coating of Holocene popcorn-like tufa not depicted.

$29.5 \mathrm{ka}$ and accelerates at $25.0 \mathrm{ka}$; (2) lake-level oscillations about the Darwin Pass spill level occur between 23.5 and $16.0 \mathrm{ka}$; there are five major oscillations with their $\delta^{18} \mathrm{O}$ maxima centered on 23.0, 20.5, 18.5 (Astor Pass Oscillation), 17.5, and $16.5 \mathrm{ka}$; (3) the Lahontan highstand is evidenced by a $\delta^{18} \mathrm{O}$ minimum at $15.5 \mathrm{ka}$, and (4) the precipitous drop in lake level after the highstand is indicated by a rapid increase in $\delta^{18} \mathrm{O}$ between 15.5 and $15.2 \mathrm{ka}$.

Some of the changes in hydrologic balance evidenced by the PLC92B $\delta^{18} \mathrm{O}$ record closely resemble the lake-level envelope described by the tufa data; however, certain differences between the two climate-proxy records are evident; e.g., the Astor Pass Oscillation defined by the tufa record is merely one of five lakelevel oscillations defined by the core-based $\delta^{18} \mathrm{O}$ record that occur between 23.5 and $16.0 \mathrm{ka}$. In addition, the tufas indicate both an earlier rise to the highstand level and a later decline from it relative to the PLC92B $\delta^{18} \mathrm{O}$ record. With respect to the evolution of lake level between 23.5 and $15.0 \mathrm{ka}$, more trust should be put in the continuous $\delta^{18} \mathrm{O}$ record of PLC92B; many of the differences between the two records probably results from the discontinuous distribution of tufa samples between 23.0 and $15.0 \mathrm{ka}$. In addition, the age distribution of tufas formed above $1308 \mathrm{~m}$ may indicate both the effects of a reservoir effect and the addition of modern carbon on the ages of the "highstand" tufas.

The $\delta^{18} \mathrm{O}$ values for PLC92B (Fig. 12C) are coincident with the mineralogic and sedimentary fabric variations that occurred within the upper part of the core. Although there is a strong agreement in the sense of change of the $\delta^{18} \mathrm{O}$ record relative to the change in sedimentary fabrics in PLC08-1 (Fig. 8), the numerical values appear to be somewhat discordant. In general, intervals with wellsorted ostracode sand lenses possess the heaviest $\delta^{18} \mathrm{O}$ values, consistent with the interpretation of very shallow-water conditions. These intervals include, however, some very light $\delta^{18} \mathrm{O}$ values that are associated with beds of greenish, low-carbonate mud. These beds are interpreted as resulting from influxes of river water that caused short-lived increases in lake level. Similarly, the upward transition from ostracode-rich to laminated sediment is coincident with lighter $\delta^{18} \mathrm{O}$ values. However, microlaminated intervals often include elevated $\delta^{18} \mathrm{O}$ values. These elevated $\delta^{18} \mathrm{O}$ intervals are interpreted as times when lake level was declining, but the lake remained sufficiently deep to preserve fine sediment lamination. Another factor affecting the relative magnitude of the $\delta^{18} \mathrm{O}$ values is the thickness of the sampling interval. Sampled intervals containing thin interlayers associated with both very depleted or enriched isotopic values resulted in a smoothing of the overall $\delta^{18} \mathrm{O}$ variability. For example, isotopically depleted thin green muds within the 5.03-3.29 m interval are thought to have decreased the overall isotopic values of the interval. In highly laminated intervals, the effect is exacerbated by the fact that the thickness of sediment representing falling lake levels was much greater than that produced by rising lake levels. The net effect is to increase the overall $\delta^{18} \mathrm{O}$ value. Examples of this phenomenon occur in laminated intervals $10.70-10.40 \mathrm{~m}$ and $9.35-8.97 \mathrm{~m}$. Thus, thicker sampling intervals result in greater suppression of the $\delta^{18} \mathrm{O}$ variability inherent in finely layered sediments. In the heavily bioturbated $3.09-0.00 \mathrm{~m}$, depleted $\delta^{18} \mathrm{O}$ values are closely associated with small burrows that are oriented parallel to the bedding plane. More enriched $\delta^{18} \mathrm{O}$ values are associated with ostracoderich mud, containing large, randomly oriented burrows. The PLC92B sedimentary record contains similar isotopic artifacts.

\subsection{The PLC97-3 TIC record of lake-level change}

In order to determine the nature of lake-level variation subsequent to the Lahontan highstand, it is preferable to turn to a parameter that is not strongly influenced by the focusing of older reworked sediment into the lake. TIC values serves well in this regard as one would expect a substantial increase in carbonate precipitation during and after the fall of Lake Lahontan as the lake becomes hydrologically closed and saline. Reworking of old (previously deposited) lake sediment during and after the fall from the Lahontan highstand would only serve to dilute the core site with TIC-poor sediment; sediment deposited during the rise to the Lahontan highstand had little TIC (Figs. 15A and 16B) as a result of its dilution by glacial rock flour.

Examining the TIC record from core PLC97-3 (Fig. 15A), TIC values remained extremely low until $14.8 \mathrm{ka}$, indicating the presence of a deep lake and rock flour input. Between 14.6 and $13.2 \mathrm{ka}$ TIC values increased, indicating the transition from a deep fresh water lake into a shallow saline lake. TIC values once again approached zero between 13.1 and $11.9 \mathrm{ka}$, signaling the presence of a rising and (or) spilling lake system.

\subsection{The PLC92B TIC and TOC records of change in the hydrologic and cryologic balances}

Fig. 16A and B display the TIC and TOC records from PLC92B for the period 48 to $14 \mathrm{ka}$. Benson et al. (1996b) have previously shown that the input of glacial rock flour to rivers headed in the Sierra Nevada tends to decrease diatom productivity within lakes fed by those rivers by decreasing light penetration and photosynthesis rates. This leads to substantial decreases in the amount of TOC stored in lake-bottom sediments. The influx of siliciclastic rock flour also tends to dilute the amount of TIC and TOC stored in the sediment.

The TOC concentrations are highly variable until $\sim 32 \mathrm{ka}$; however, after $32 \mathrm{ka}$, TOC concentrations decrease and are much less variable, indicating dilution via the influx of rock flour input from Sierran alpine glaciers (Fig. 16A). Note that the advance of Sierra Nevada alpine glaciers occurred at about the same time as the rise in level of Lake Lahontan (compare Figs. 12C and 16A). Pyramid Lake TIC values also tend to parallel Pyramid Lake $\delta^{18} \mathrm{O}$ values in a general sense, with elevated TIC values being associated with elevated $\delta^{18} \mathrm{O}$ values between 35 and $16 \mathrm{ka}$ (compare Figs. $12 \mathrm{C}$ and $16 \mathrm{~B}$ ). This suggests that both the TIC and $\delta^{18} \mathrm{O}$ records primarily reflect changes in the hydrologic balance of Lake Lahontan during this time period. 

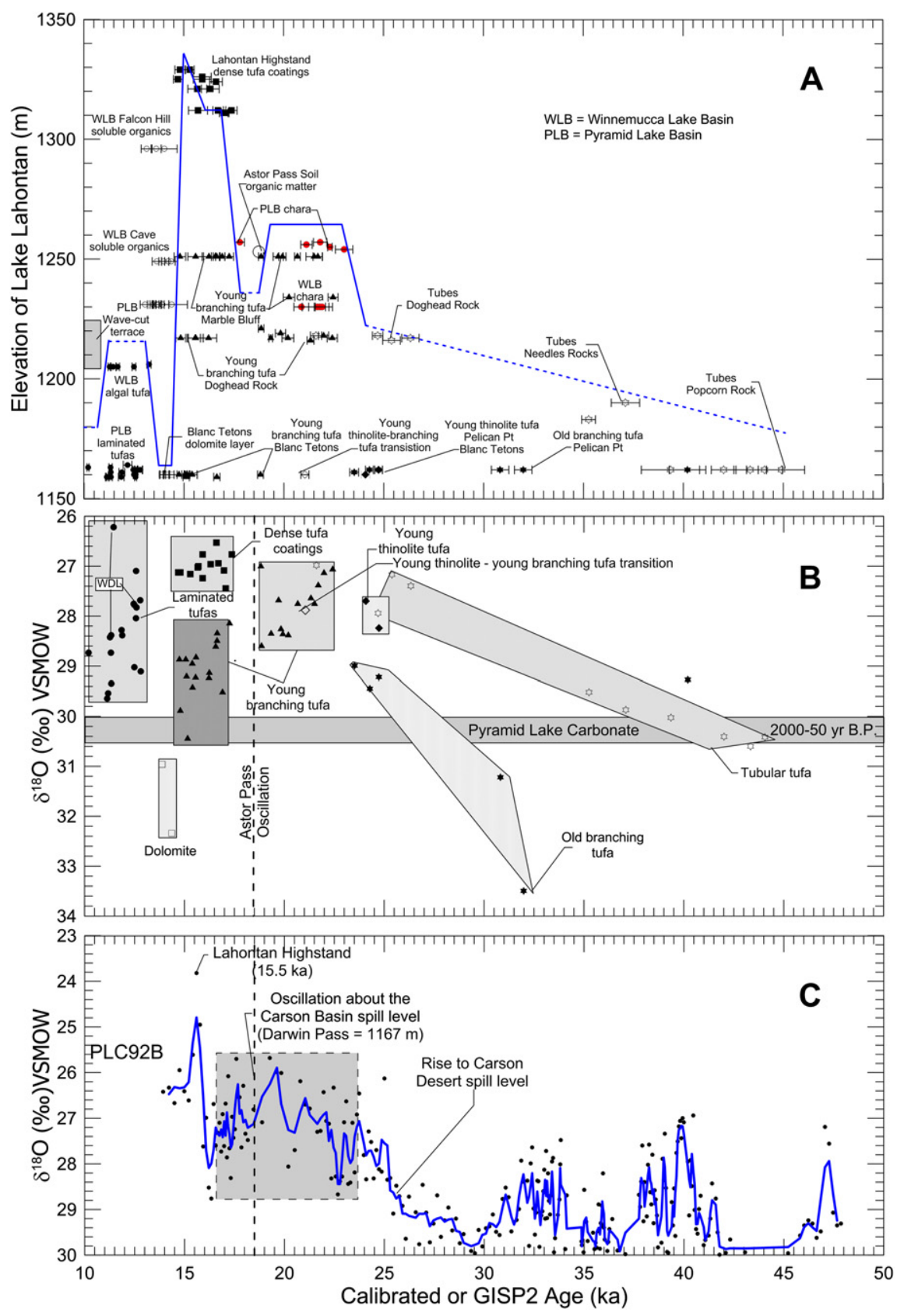

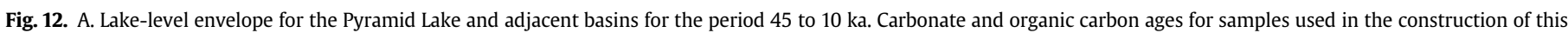

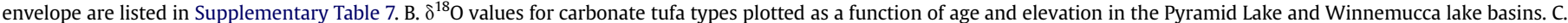
The $\delta^{18} \mathrm{O}$ record from core PLC92B.

\subsection{GISP2 calendar ages of tephras in cores PLC08-1 and PLC92B}

Numerous tephra layers, some of which contain more than one tephra, were sampled and analyzed with the electron microprobe (Supplementary Table 8). In PLC08-1, the Trego Hot Springs Bed occurs as a single sample at $4.55 \mathrm{~m}$ and the Wono Bed occurs as a single thick sample between 7.30 and $7.20 \mathrm{~m}$. The Wono Bed also was found lower in PLC08-1 at 8.05-8.00 $\mathrm{m}$ and 8.17-8.15 $\mathrm{m}$ where it was introduced by the coring operation (chemical matches not shown).

The single tephra at $7.58 \mathrm{~m}$ is probably the Carson Sink Bed (of the Mono Formation). Ash 15 was first found within the Wilson Creek Formation at Mono Lake; however, Ash 15 can also be found in numerous locations around the Mono Lake basin, including Mill Creek. Except for its Fe oxide content, the tephra at $7.58 \mathrm{~m}$ is an excellent compositional match to the Carson Sink Bed; the inclusion of the Fe oxide value diminishes the value of the similarity coefficients (SC) from 0.97 to 0.99 to $0.95-0.96$. Given its unique trace-element composition (see Table 1 in Benson et al., 2003), the Carson Sink Bed can be shown to be equivalent to Wilson Creek Ash 15, which was deposited during the Mono Lake magnetic excursion. This implies that the Mono Lake excursion occurred 7 ka after the Laschamp magnetic excursion, and is not equivalent to that excursion as previously suggested by Kent et al. (2002) and Zimmerman et al. (2006).

The silica content of the tephra at $7.73 \mathrm{~m}$ is distinctly lower than that of the other tephras. Its glass composition indicates a weak match $(\mathrm{SC}=0.94)$ to the Wadsworth Bed (of the Eetza Formation) which is thought to be older than $168 \mathrm{ka}$. Given its age and 


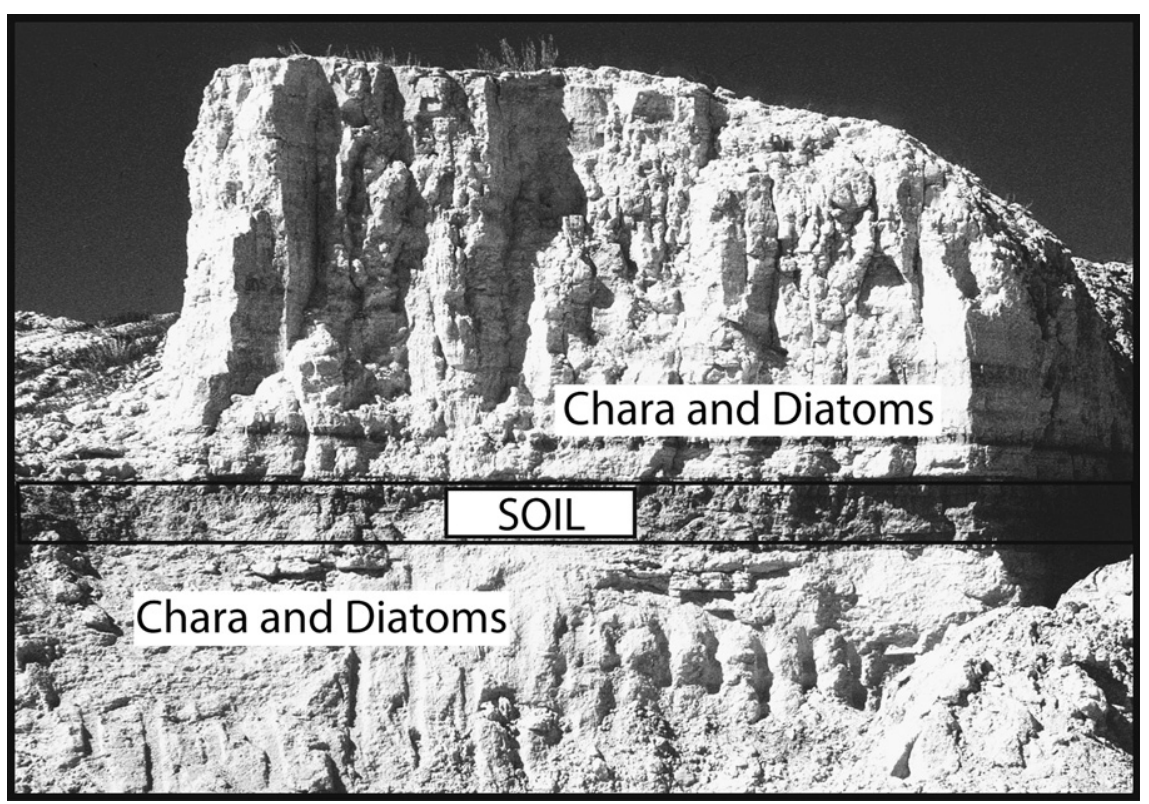

Fig. 13. The chara-diatom deposit at Astor Pass. The soil in the picture is at an elevation of $1253 \mathrm{~m}$ and is floored by a sandy beach deposit.

stratigraphic position, this tephra is likely is likely to have been redeposited. The Timber Lake Bed (of the Pyramid Lake Member of the Mount Mazama Formation) observed in the Pyramid Island core (JOD-11) (Benson et al., 2003) was not observed in core PLC08-1.

Two tephra samples found at 15.51 and $15.44 \mathrm{~m}$ in PLC08- 1 each appear to be mixtures of three tephras, which is suggested by significant variability in glass shard composition as reflected in the high standard deviations of oxide weight percents. The glass data for both samples can be divided into three compositional subgroups. The most abundant glass in both samples is an excellent match ( $\mathrm{SC}=0.98$ ) to the Mount St Helens Cy tephra, which in the Lahontan Basin is known as the Marble Bluff Bed. Other excellent matches ( $\mathrm{SC}=0.97$ and 0.98 , respectively) are to the Summer Lake tephra Bed $\mathrm{O}$ (glass 1 at $15.44 \mathrm{~m}$ ) and to the Mount Mazama Pumice Castle-like tephra 1of Davis (1985) (glass 1 at $15.51 \mathrm{~m}$ ). Less reliable matches ( $\mathrm{SC}=0.95$ and 0.94 , respectively) were found to Carp Lake Ash 13 (glass 2 at $15.44 \mathrm{~m}$ ) and to the Rockland tephra (glass 2 at $15.51 \mathrm{~m}$ ).

Given the GISP2-based time scale for PLC08-1, the calendar ages of the Trego Hot Springs, Wono, Carson Sink, and Marble Bluff tephras are, respectively, 29.9, 33.7, 34.1, and $43.2 \mathrm{ka}$. While it is possible the Marble Bluff Bed/Mount St. Helens Cy tephra was washed into Pyramid Lake after its original time of deposition, its PLC08-1 based date is consistent with previous age estimates; e.g., Berger and Busacca (1995) suggested a date of $47 \pm 2$ ka obtained using thermoluminescence. The age of the supposed Timber Lake Bed in PLC92B is nearly the same as the age of the Carson Lake Bed in PLC08-1. With the help of Rob Negrini and Andre Sarna-Wojcicki we took a new look at the major element chemistry of the Timber Lake Bed. Its chemistry is consistent with a Mono Craters origin (Carson Sink Bed) and not a Cascadian (Timber Lake Bed) origin. Thus the tephra found at $8.5 \mathrm{~m}$ below the sediment-water interface (including $20 \mathrm{~cm}$ of Trego Hot Springs tephra) is most likely the Carson Sink Bed.

\section{Discussion}

Both discontinuous and continuous records of change in the hydrologic balance of Lake Lahontan, that span part or most of the 48.0-11.5 ka time period, have been presented. The discontinuous tufa elevation and tufa $\delta^{18} \mathrm{O}$ records as well as the continuous PLC97-3 TIC record are based on a calibrated ${ }^{14} \mathrm{C}$ time scale that was not corrected for a carbon-reservoir effect. It is possible that a reservoir effect of several hundred years existed during times when lakes in the Lahontan Basin were shallow and hydrologically closed. For example, in the late Holocene, the value of the reservoir effect approached $600 \mathrm{y}$ in the Pyramid Lake basin (see Fig. 14 in Benson et al., 2002). When lakes in the Lahontan Basin were either deep and(or) rapidly overflowing, the reservoir effect would have been minimal - probably on the order of $<200 \mathrm{y}$ - given that the dissolved inorganic carbon concentration of lake water was low and wind velocities were high, promoting efficient exchange of dissolved and atmospheric $\mathrm{CO}_{2}$ (Kutzbach and Guetter, 1986; Benson, 1993). Therefore, the reservoir effect was small between 25.0 and 15.5 ka (Figs. 12C and 17A and B) and between 13.2 and 11.3 and that the calibrated dates from PLC97-3 are reasonably accurate.

The age models for PLC08-1 and PLC92B are based on the correlation of PSV signatures in PLC08-1 with similar PSV signatures in North Atlantic marine sediment cores whose $\delta^{18} \mathrm{O}$ and sedimentological records could be tied to the GISP2 $\delta^{18} \mathrm{O}$ record. The available $\delta^{18} \mathrm{O}$, TIC, TOC, and sedimentological records from the Pyramid lake sediment cores were compared to the $\delta^{18} \mathrm{O}$ record from the Greenland GISP2 ice core whose time scale has been established via documentation of annual ice layers that formed over the past $\sim 50,000$ years (Alley et al., 1997).

\subsection{A synthesis of prehistoric change in the hydrologic balance of Lake Lahontan}

The continuous and discontinuous records of change in the hydrologic balance of Lake Lahontan yield a relatively consistent history of change in the size of Lake Lahontan/Pyramid Lake. Between 48.0 and $32.0 \mathrm{ka}$, the sedimentologic and isotopic records indicate that lake levels were highly variable in the Pyramid Lake basin but that levels were generally lower than lake level between 25.0 and $15.0 \mathrm{ka}$.

During the $32.0-23.5 \mathrm{ka}$ time interval, the tufa elevation, tufa $\delta^{18} \mathrm{O}, \mathrm{PLC08}-1$ sedimentologic, and PLC92B and PLC08- $1 \delta^{18} \mathrm{O}$ records all indicate a rise in lake level to the Darwin Pass spill point (1265 m). The Wono and Trego Hot Springs tephras have GISP2 calendar ages of, respectively, 33.7 and $29.9 \mathrm{ka}$. The data indicate that Lake Lahontan was deep before and after deposition of the Trego Hot Springs Bed; however, both the sedimentary (ostracode 

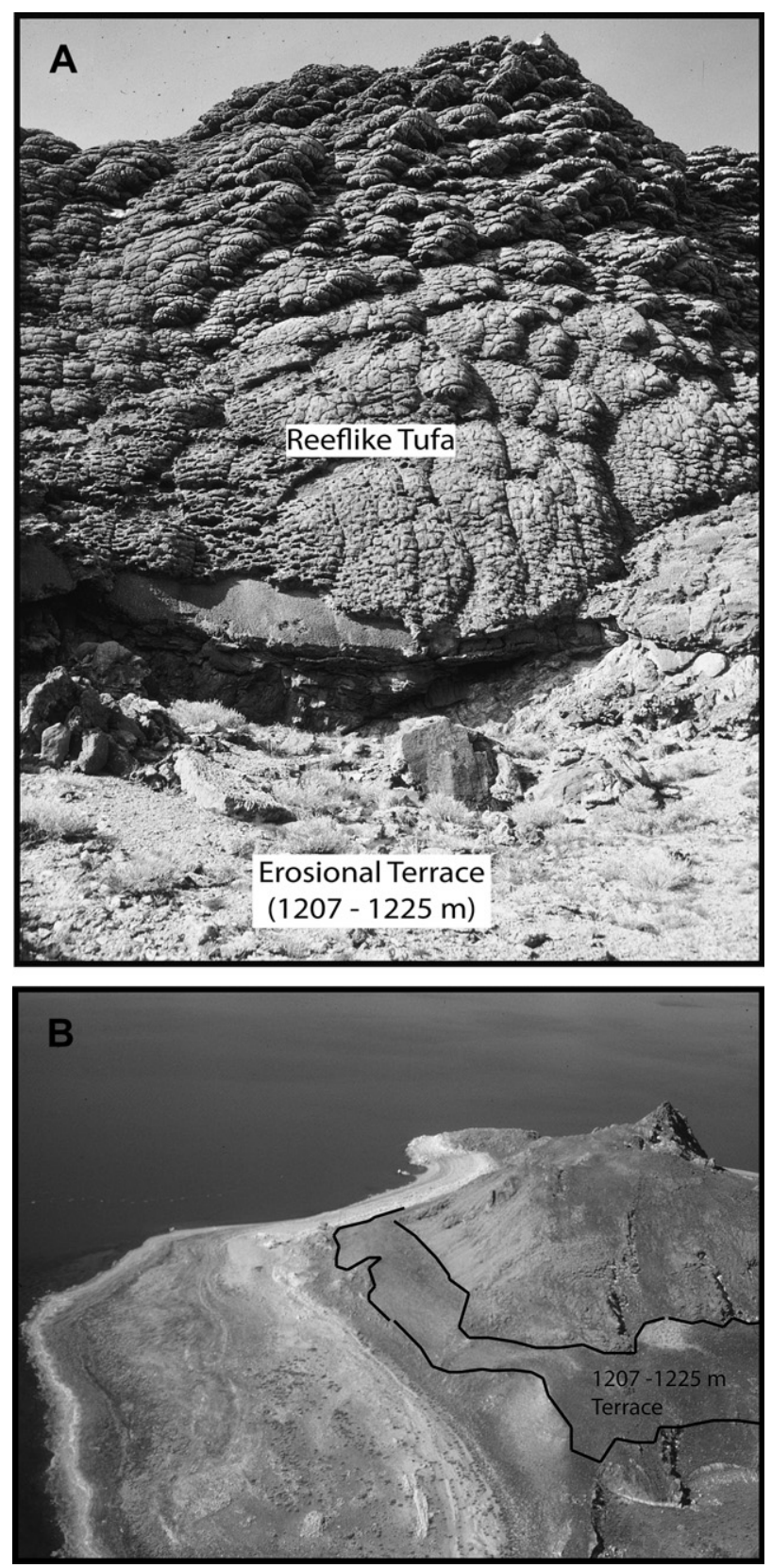

Fig. 14. A. The 1207-1225 m Younger Dryas erosional terrace at the Marble Bluff site with massive reef-life tufa above the terrace. B. The 1207-1225 m Younger Dryas erosional terrace on Anaho Island.

sands) and $\delta^{18} \mathrm{O}$ (highly enriched values) records demonstrate that the lake was extremely shallow during and shortly after deposition of the tephra. In addition, the Wono Bed was deposited during an interval of enriched $\delta^{18} \mathrm{O}$ values (Fig. 17) and falling lake level. Adams (2010) has suggested that the Wono and Trego Hot Springs beds were deposited when lake levels were at, respectively, 1217 and $1254 \mathrm{~m}$. In Supplementary Appendix 2, both sedimentologic and isotopic data show that his estimate of lake elevation during deposition of the Wono Bed is probably correct. However, his estimate of lake elevation during deposition of the Trego Hot Springs Bed is excessive; i.e., lake elevation could have been no greater than 1208-1220 $\mathrm{m}$ and may have been significantly lower.

Between 23.5 and $15.5 \mathrm{ka}$, the PLC92B $\delta^{18} \mathrm{O}$ record displays a great deal of variability with major $\delta^{18} \mathrm{O}$ maxima occurring at
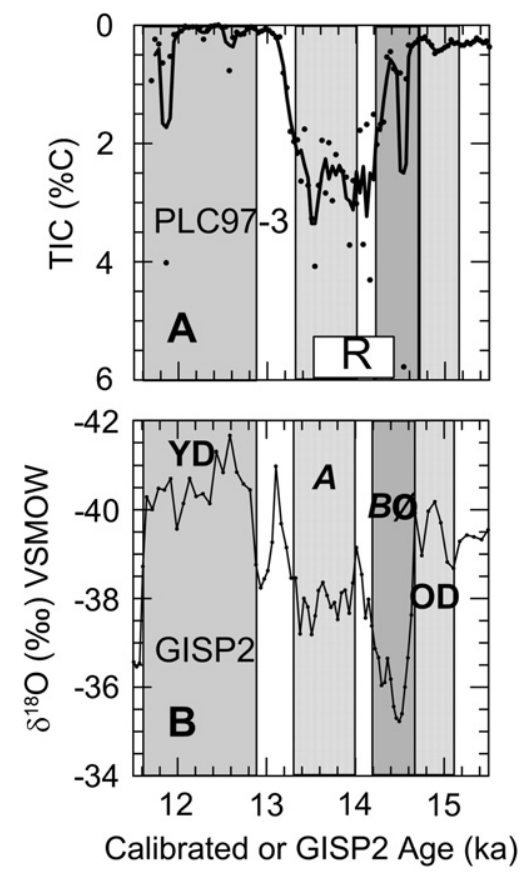

Fig. 15. A. The TIC record from core PLC97-3 compared with B. the $\delta^{18} \mathrm{O}$ record from GISP2 for the period 15.5 to $11.5 \mathrm{ka}$. YD, A, BØ, and OD refer, respectively, to the Younger Dryas, Allerød, Bølling, and Oldest Dryas events. The white box labeled with " $\mathrm{R}$ " indicates the zone of reworked sediment in PLC97-3.
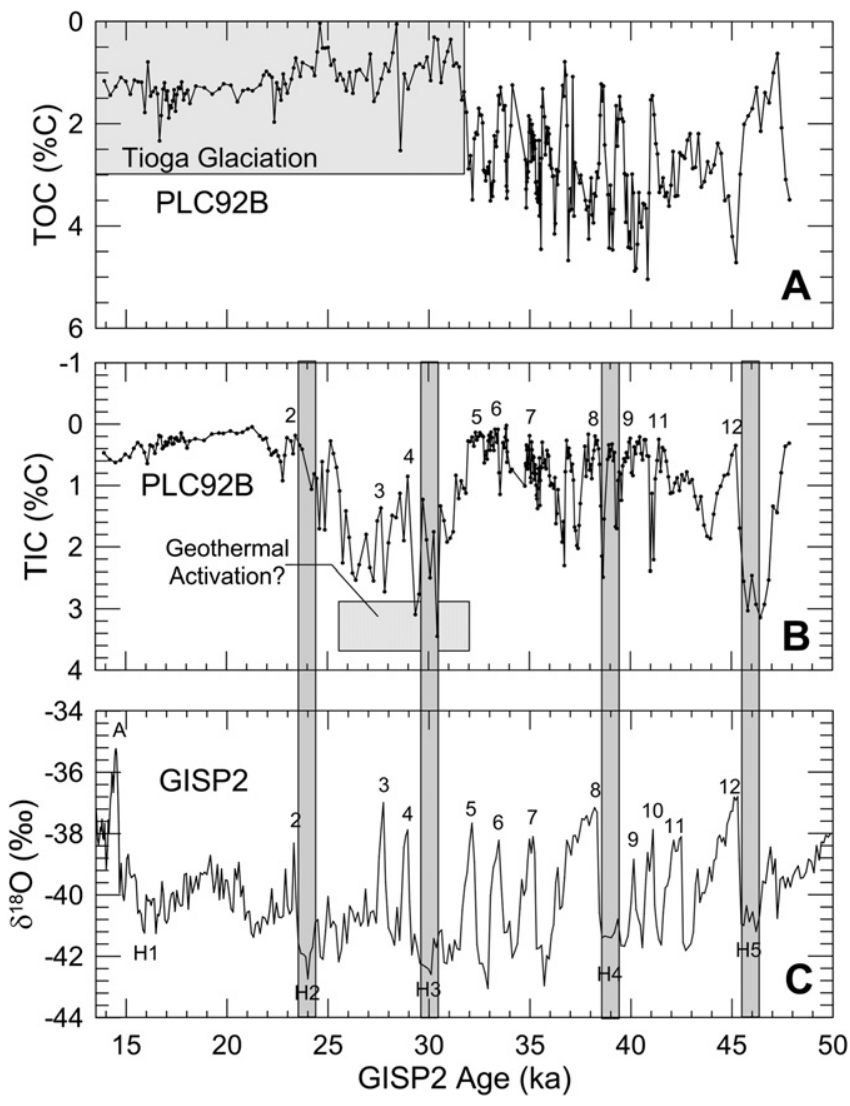

Fig. 16. A. TOC and B. TIC records from core PLC92B compared with the C. GISP2 $\delta^{18} \mathrm{O}$ record. Heinrich $(\mathrm{H})$ events in the GISP2 ice core tend to be associated with relatively dry times (elevated TIC concentrations) at Pyramid Lake. The numbers in the GISP2 record refer to Dansgaard-Oeschger oscillations. Geothermal input of Ca-rich water beginning at about 32 ka may have initiated a major episode of tufa deposition. 

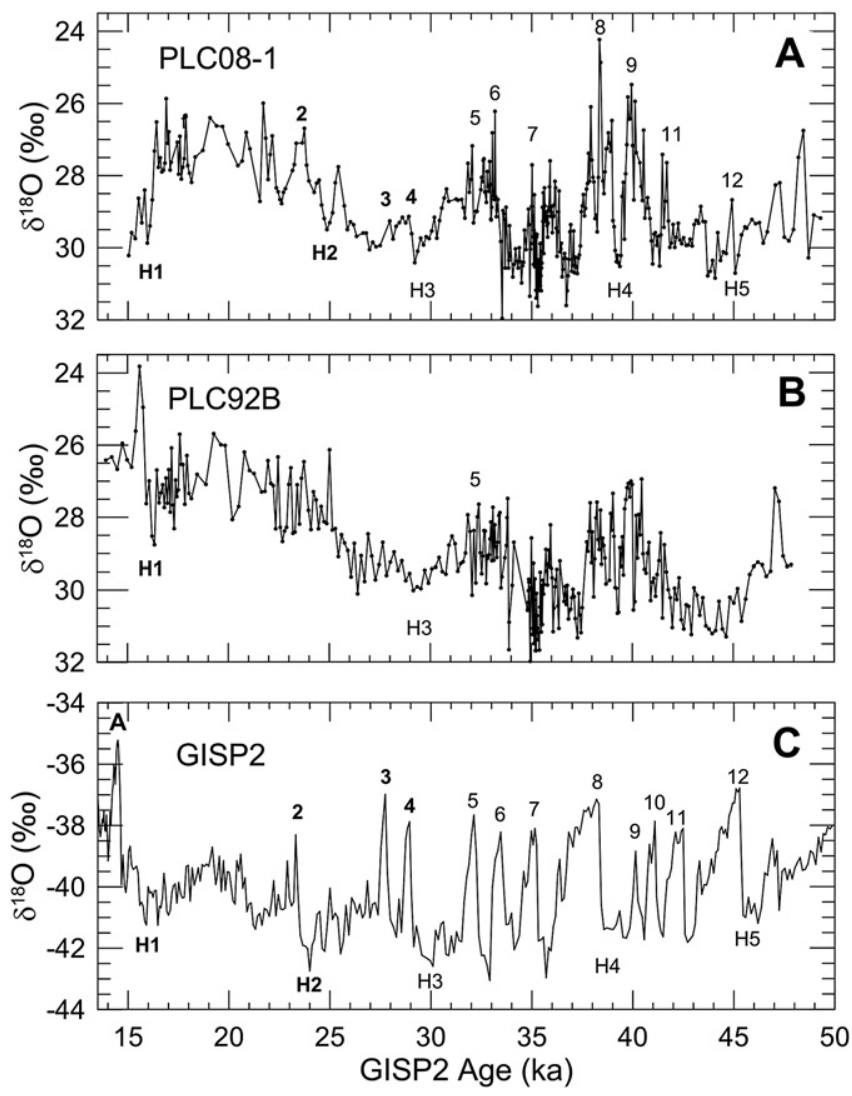

Fig. 17. The $\delta^{18} \mathrm{O}$ records from cores A. PLC08-1 and B. PLC92B compared with C. the GISP2 $\delta^{18} \mathrm{O}$ record. Many of the GISP2 features can be correlated to PLC08-1. The $\delta^{18} \mathrm{O}$ record of PLC92B is much "nosier" than that of PLC08-1, but the overall shape of the two records is nearly identical.

23.0, 20.5, 18.5, 17.5, and $16.5 \mathrm{ka}$. These maxima represent low points in lake-level oscillations that reached below the Darwin Pass spill level.

The tufa elevation record between 25 and $15.2 \mathrm{ka}$ is not as complex at the PLC92B $\delta^{18} \mathrm{O}$ record. Only one oscillation, the Astor Pass Oscillation at $\sim 18.5 \mathrm{ka}$, is identifiable in the tufa-based lakelevel record. However, the tufa $\delta^{18} \mathrm{O}$ record for this time period indicates a high degree of variability, supporting the concept that western Lahontan Basin lakes were intermittently spilling water to the Carson Desert basin. Numerous oscillations in lake level are also indicated in the sedimentologic record between 23.9 and $16.1 \mathrm{ka}$.

Calcite is present in the basal section of PLC97-3 between 4.32 and $4.25 \mathrm{~m}(18.8-18.7 \mathrm{ka})$; aragonite is present between 4.25 and $3.85 \mathrm{~m}(18.7-17.5 \mathrm{ka})$, and calcite and aragonite alternate within the 3.85 - to $3.47-\mathrm{m}(17.5-16.2 \mathrm{ka}$ ) interval (Table 1). These data indicate the presence of a deep rapidly spilling lake between 18.8 and $18.7 \mathrm{ka}$; a lake that probably fell below the Darwin Pass spill point between 18.7 and $17.5 \mathrm{ka}$, and a lake that oscillated between times of hydrologic closure and spill between 17.5 and $16.2 \mathrm{ka}$.

The PLC92B $\delta^{18} \mathrm{O}$ record indicates that after $16.0 \mathrm{ka}$ the lake rose rapidly, reaching its highstand state in about $500 \mathrm{y}$ (Fig. 17B). The $\delta^{18} \mathrm{O}$ value $(23.8 \%$ o $)$ that signals the presence of the highstand represents a 150-y average; therefore, Lake Lahontan did not maintain this elevation very long. The timing and rapidity of the ascension of Lake Lahontan to its highstand state does not appear to be supported by the tufa-based lake-level envelope, which indicates that the lake was already above $1308 \mathrm{~m}$ by $17 \mathrm{ka}$. Note, however, that $<26 \% \delta^{18} \mathrm{O}$ values associated with the sedimentbased lake-level record (Fig. 17B) are not recorded by tufas found above $1308 \mathrm{~m}$ (Fig. 12B). It is, therefore, possible that many of the high-elevation tufas did not form during the Lahontan highstand and that many were deposited prior to the highstand. Carbonate tufas in the subaerial environment can take on modern ${ }^{14} \mathrm{C}$ when acidic rain dissolves some of the surface carbonate and the aqueous solution, which contains both old and modern carbon, infiltrates the porous tufa, evaporates, resulting in the reprecipitation of calcium carbonate. This process shifts the bulk age of the tufa to values younger than the time of original carbonate formation. This would imply that at least part of the PLC92B $\delta^{18} \mathrm{O}$ record between 17 and $15.5 \mathrm{ka}$ represents lake levels that greatly exceeded the Darwin Pass spill point (1265 m) and possibly also the Adrian Valley spill point $(1308 \mathrm{~m})$. A calibrated date of $15.8 \pm 0.3 \mathrm{ka}$ date on camel bone found in lake sediments at an elevation of $1310 \mathrm{~m}$ (Adams and Wesnousky, 1999) is consistent with the $\delta^{18} \mathrm{O}$ record.

The tufa-based $\delta^{18} \mathrm{O}$ record for the period 17.0-14.9 ka indicates that the low- and medium-elevation reef-like branching tufas possess substantially more enriched isotopic values than highelevation dense tufa coatings (Fig. 12B). This suggests the possibility that the lake was, at times, stratified with buoyant fresh water, overlying a saline bottom water of greater density. The 17.0-14.9 ka period in PLC97-3 is represented by a sediment-core depth ranging from 3.70 to $3.12 \mathrm{~m}$ (Fig. 6). Calcite is present between 3.47 and $3.07 \mathrm{~m}$, which is consistent with precipitation from the upper waters of a stratified lake. In addition, sediments deposited between 3.47 and $3.43 \mathrm{~m}(16.3-16.1 \mathrm{ka})$ and 3.33-3.06 m (15.8-14.8 ka) are unburrowed or contain horizontal burrows, which is consistent with the existence of anoxic bottom water within a stratified lake.

The PLC92B $\delta^{18} \mathrm{O}$ record indicates that Lake Lahontan fell precipitously from its highstand over a period of $300 \mathrm{y}$ (Fig. 17B), whereas the somewhat less precise tufa-based lake-level envelope indicates a value closer to $500 \mathrm{y}$ (Fig. 12A). Assuming that the lake fell to an elevation of $1175 \mathrm{~m}$ in $300 \mathrm{y}$, it fell at an average rate of $0.53 \mathrm{~m} / \mathrm{y}$. This rate of lake-level decline was previously simulated by Hostetler and Benson (1990) who imposed a present-day Lahontan Basin hydrologic balance on pluvial Lake Lahontan at its highest level.

After lake level bottomed out at $15.2 \mathrm{ka}$, dolomite eventually formed from the Mg-rich, saline lake water. This dolomite, which forms a thin layer coating tufa mounds that line the Pyramid Lake shoreline, has ages ranging from 14.4 to 13.9 ka (Fig. 10C, Supplementary Table 7). This dolomite was found at a depth of $2.97 \mathrm{~m}$ in PLC97-3 (Fig. 6).

There is a 700-y hiatus in carbonate deposition between the youngest dolomite date ( $13.9 \mathrm{ka}$ ) and the oldest date on a thin layer of dense laminated tufa $(13.2 \mathrm{ka})$ that coats the dolomite (Supplementary Table 7 ). The PLC92B $\delta^{18} \mathrm{O}$ record only extends to $13.8 \mathrm{ka}$ and does not provide information with regard to the 13.9-13.2 ka carbonate hiatus. However, the PLC97-3 TIC record indicates that a substantial amount of TIC precipitated from Pyramid Lake between 14.4 and $13.3 \mathrm{ka}$, indicating the presence of a shallow lake that infrequently overflowed to the Winnemucca Lake basin (Fig. 15A). The carbonate that precipitated from the lake during this time period was composed of aragonite (Table 1), which also suggests the existence of a shallow, somewhat-saline water body. Lake depth at this time may have been often below the elevation of the tufa deposits that line the shores of present-day Pyramid Lake.

The undisturbed sediment in PLC97-3, that was deposited between 14.4 and $13.3 \mathrm{ka}(2.97-2.59 \mathrm{~m})$, is highly laminated and burrow free, which suggests that the lake was probably stratified and contained anoxic bottom water. This anoxic state may have prevented the continued growth of the dendritic form of tufa which may have owed its existence to cyanobacteria (Kempe et al., 1990).

The TIC concentration in PLC97-3 began to sharply decrease beginning at $13.3 \mathrm{ka}$ and by $13.1 \mathrm{ka}$ it was essentially zero (Fig. 15A). 
The TIC concentration in PLC97-3 stayed at very low levels until $\sim 11.9 \mathrm{ka}$ at which time it oscillated. Most of the undisturbed sediment deposited between 13.3 and $11.9 \mathrm{ka}(2.59-2.04 \mathrm{~m})$ is laminated and unburrowed, excepting the 12.8-12.5 ka $(2.42-2.36 \mathrm{~m})$ interval (Fig. 6). In addition, the carbonate mineralogy oscillated between aragonite and calcite, suggesting the presence of a stratified lake that may have undergone changes in volume.

Between 13.2 and $11.1 \mathrm{ka}$, dense, laminated, calcitic tufa coated low-elevation tufa mounds that line the present lake shore (Supplementary Table 7; Fig. 10C). The large $\delta^{18} \mathrm{O}$ range of these tufas (Fig. 12A) and the elevation of an algal calcitic tufa in the Winnemucca Lake basin (1205 $\mathrm{m}$ ) suggest the presence of a relatively deep, sometimes-stratified lake that intermittently spilled to the Smoke Creek-Black Rock Desert basin. Erosional terraces on Anaho Island, Marble Bluff, and at other sites (Fig. 14) suggest that the lakes in the Pyramid, Winnemucca, and Smoke Creek-Black Rock Desert basins may have coalesced at times between 13.2 and $11.3 \mathrm{ka}$, having risen to elevations between 1205 and $1227 \mathrm{~m}$.

\subsection{Comparison of climate-proxy records from the Lahontan Basin} with the GISP2 $\delta^{18} \mathrm{O}$ record

The $\delta^{18} \mathrm{O}$ record from a Great Basin lake primarily reflects a change in the hydrologic balance of the lake, whereas the $\delta^{18} \mathrm{O}$ record from an ice core primarily reflects changes in air temperature, and to a lesser extent, changes in the source region of the air mass from which precipitation occurred (Alley, 2000).

The PLC92B $\delta^{18} \mathrm{O}$ record is preferred over the PLC08- $1 \delta^{18} \mathrm{O}$ record for times after 16 ka because the youngest part of the PLC081 sediment record has been reworked. A comparison of the two sediment-based $\delta^{18} \mathrm{O}$ records with the GISP2 ice-core $\delta^{18} \mathrm{O}$ record for the period 48-14 ka (Fig. 17) indicates a certain degree of similarity between the lacustrine and ice-core $\delta^{18} \mathrm{O}$ records. The cooccurrence of DO interstades with Pyramid Lake wet events prior to 16 ka suggests that the Lahontan Basin became wetter when Greenland became warmer. In addition, lake-level minima (dry events) can be associated with Heinrich cold events, although Heinrich events 3 and 4 appear to precede falling lake levels by a few hundred years.

In examining the PLC92B and GISP2 $\delta^{18} \mathrm{O}$ records during the period 16 to $13.8 \mathrm{ka}$ (Fig. 18), it becomes abundantly clear that the Lahontan wet events, including and after the highstand, were associated with GISP2 cool intervals. Therefore, it appears that after the highstand, elevated lake levels became associated with cold Greenland air temperatures and vice versa.

Comparing both the TIC record from core PLC97-3 (Fig. 15A) and the tufa-based lake-level record (Fig. 12A) with the GISP2 $\delta^{18} \mathrm{O}$ record for the period 15.5 to $11.7 \mathrm{ka}$ (Fig. 15B), the Oldest Dryas interval was a time of low TIC content, that the Bølling warm event witnessed an oscillation in TIC, that the Allerød warm event witnessed a massive increase in TIC, and that TIC values approached zero during much of the Younger Dryas event. The latter observation supports tufa-based lake-level data (Fig. 12A), which indicate that Younger Dryas event (12.9-11.6 ka) was associated with relatively high lake levels in the Lahontan Basin.

Thus, prior to the Lahontan highstand, elevated lake levels were associated with warm Greenland air temperatures; however, subsequent to the highstand, elevated lake levels were associated with cold Greenland air temperatures. Questions, therefore, remain as to the nature and polarity of the link between temperature in the North Atlantic and the relative wetness of the Lahontan Basin.

Fig. 19B is a record of sea level reconstructed from coral depths and their U/Th ages (Thompson and Goldstein, 2006). The sea-level record reflects the amount of ice stored in glaciers; the lower the
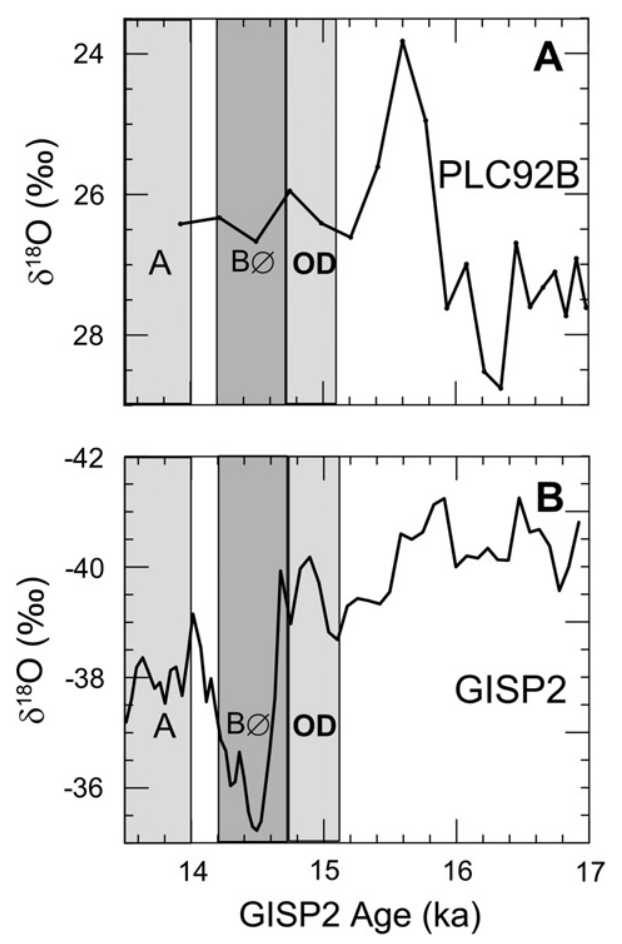

Fig. 18. The $\delta^{18} \mathrm{O}$ record from core PLC92B compared with the GISP2 $\delta^{18} \mathrm{O}$ record for the period 17 to $13.5 \mathrm{ka}$. A, BØ, and OD refer to the Allerød, Bølling, and Oldest Dryas intervals. Note that the maxima and minima in both $\delta^{18} \mathrm{O}$ records are nearly synchronous in time but not in magnitude.

sea level the larger the ice mass. If this record is assumed to generally reflect the size of the LIS, it is clear that the existence of an exceptionally large ice sheet (the gray-shaded area in Fig. 19B) somehow linked warm Greenland air temperatures with increases in the size of Lake Lahontan between $~ 30.0-15.5$ ka (Fig. 19A). When the ice sheets decayed to the point that sea level rose above $-80 \mathrm{~m}$ (relative to present-day sea level), the temperaturewetness polarity reversed (Figs. 15 and 18).

With respect to more catastrophic events that affected the size and shape of the LIS, Dyke et al. (2002) have suggested that H1 "probably drew down the entire central ice surface", which was positioned over Hudson Bay. Such a change in topography should have affected the northern hemisphere windfield, including the trajectory of the polar jet stream (PJS) in agreement with the hypothesis of Wunsch (2006). Bintanja et al. (2005) have calculated the amount of water stored in the LIS during the past $1.2 \mathrm{Ma}$. These data were used for the time interval just prior to $\mathrm{H} 2$ and $\mathrm{H} 1$ and estimates of sea level change, ranging from 2 to $15 \mathrm{~m}$, to calculate the percentage of LIS ice transported to the North Atlantic during a Heinrich event, assuming all the ice came from the LIS. The calculations indicate values ranging from $\sim 3$ to $25 \%$ of the total mass of the LIS (Table 2). Accepting the statement of Dyke et al. (2002) with regard to H1 and the apparent increase in sea level during H2 suggested by Fig. 19B, a large percentage of the LIS may have been lost to the North Atlantic during both Heinrich events, and the resulting change in size and shape of the LIS may have influenced the positioning of the PJS over the western United States.

\subsection{Comparison of climate-proxy records from the Lahontan and Bonneville basins}

Fig. 20 shows the $\delta^{18} \mathrm{O}$ and TIC records from Bonneville core BL04-4 and Pyramid Lake core PLC08-1. The $\delta^{18} \mathrm{O}$ record of the 

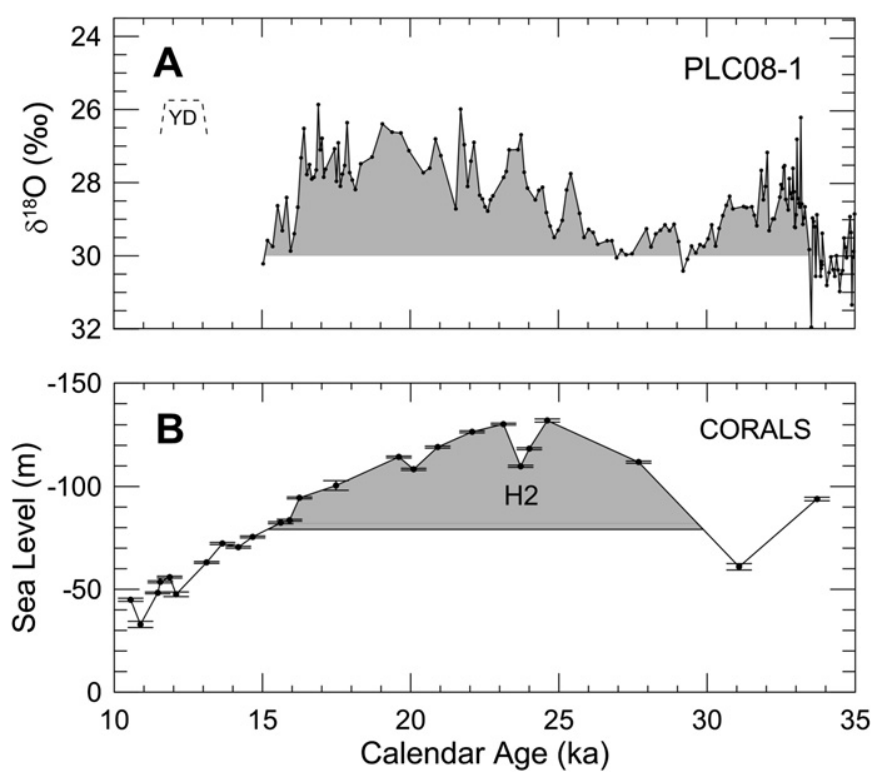

Fig. 19. A. The $\delta^{18} \mathrm{O}$ record from core PLC08-1 compared with B. a coral-based reconstructed sea-level record for the period 35 to $10.5 \mathrm{ka}$. The Lake Lahontan wet period that occurred during Younger Dryas event is shown schematically by a dashed line. Gray-shaded region of sea-level curve indicates time interval when sedimentbased $\delta^{18} \mathrm{O}$ records from Pyramid Lake resemble GISP2 $\delta^{18} \mathrm{O}$ record; lake size waxes and wanes with waxing and waning of LIS.

Lahontan highstand from the PLC92B record has been superimposed on the PLC08-1 $\delta^{18} \mathrm{O}$ record (Fig. 20C). Suggested matches between the four climate-proxy records and DO oscillations are shown as circled numbers corresponding to the interstadials events.

\subsubsection{Comparison of $\delta^{18} \mathrm{O}$ records}

The $\delta^{18} \mathrm{O}$ records of both the Lahontan and Bonneville records contain $\delta^{18} \mathrm{O}$ minima that can be matched to DO oscillations 11 (and possibly 12 ), 9-5, 3, and 2 (Fig. 20C and D). Both records also show matching $\delta^{18} \mathrm{O}$ minima at $43.5,31.1,22.2$, and $17.2 \mathrm{ka}$. Both records indicate that relatively low lake levels ( $\delta^{18} \mathrm{O}$ maxima) occur during Heinrich events $\mathrm{H} 4, \mathrm{H} 3$, and $\mathrm{H} 2$, although the evidence of a $\delta^{18} \mathrm{O}$ maximum during $\mathrm{H} 2$ in the Lahontan Basin is weak. Both records also show a double oscillation in lake volume at the time of the Stansbury Oscillation, and the $\delta^{18} \mathrm{O}$ values of both records are depleted between 24 and $16 \mathrm{ka}$, indicating the presence of large lakes in both basins. The PLC08-1 record does not extend to the isotopically light Gilbert event (13.1-11.6 ka); however, the tufabased lake-level record (Fig. 12A) indicates a comparable wet period in the Lahontan Basin.

\subsubsection{Comparison of TIC records}

The TIC records of both the Lahontan and Bonneville records contain TIC minima that can be matched to DO oscillations 11, 9-5, 3, and 2 (Fig. 20A and B). Many of the TIC minima in PLC92B, unlike those in BL04-4, approach a zero value, perhaps also indicating the effect of pre-Tioga glacial advances on the TIC concentration of Pyramid Lake sediments. The PLC92B core site would have been

Table 2

Percent reduction in size of Laurentide Ice Sheet.

\begin{tabular}{lllll}
\hline Heinrich event & \multicolumn{4}{l}{ Increase in sea level } \\
\cline { 2 - 5 } & $2 \mathrm{~m}$ & $5 \mathrm{~m}$ & $10 \mathrm{~m}$ & $15 \mathrm{~m}$ \\
\hline $\mathrm{H} 1$ & 3.1 & 7.7 & 15.4 & 23.1 \\
$\mathrm{H} 2$ & 3.3 & 8.3 & 16.7 & 25.0 \\
\hline
\end{tabular}

more "sensitive" to the input of glacial rock four than the BL04-4 core site, which was situated on the western side of Lake Bonneville, far removed from glacial sources within mountain ranges bordering the eastern side of the Bonneville Basin. The TIC record from the Bonneville Basin clearly indicates relatively low lake levels during Heinrich events $\mathrm{H} 4, \mathrm{H} 3$, and H2; however, the TIC record from the Lahontan Basin has maxima that are slightly offset from $\mathrm{H} 4, \mathrm{H} 3$, and $\mathrm{H} 2$. In general, little TIC was deposited in either the Lahontan or Bonneville basins between 24 and $16 \mathrm{ka}$, indicating the presence of large lakes in both basins. The PLC08-1 record does not overlap the TIC-depleted Gilbert event; however, core PLC97-3 (Fig. 15A) records a wet event during the same time span in the Lahontan Basin.

\subsection{Hydrothermal groundwater injection into the Pyramid Lake basin between 32 and $25.5 \mathrm{ka}$}

A very large amount of TIC was deposited in Pyramid Lake sediments between 32 and $25.5 \mathrm{ka}$ (Fig. 16B), during the initial rise of Lake Lahontan to the Darwin Pass spill level (Fig. 12C). Carbonate tubes formed at Doghead Rock during at least the latter half of this interval, suggesting that a major change in the hydrologic balance was initiated at $\sim 32 \mathrm{ka}$, which may have involved a large influx of Ca-rich geothermal water into the Pyramid Lake basin (see Table 3 in Benson et al., 1995 for a listing of hydrothermal water chemistry). This injection of geothermal water may explain the existence of many of the old tubular tufas found at the bases of tufa mounds ringing the lake (e.g., Needles Rocks, Fig. 10A and B). In the historic period, the only places where substantial carbonate deposition has occurred include the Needles Rock and Pyramid Island sites, both of which are associated with geothermal springs.

\subsection{The climate experienced by the first western Native Americans}

Recent studies of human coprolites discovered in Paisley 5-Mile Point cave in south-central Oregon indicate a brief human occupation at $12,400 \pm 60{ }^{14} \mathrm{C}$ B.P. $(14.4 \pm 0.2 \mathrm{ka})$ (Gilbert et al., 2008). Thus, the timing of these apparent "First Americans" occurred simultaneously with the decrease in wetness that followed the precipitous fall of Lake Lahontan from its highstand. Approximately $1000 \mathrm{y}$ later (13.1-12.8 ka), during the early part of the Younger Dryas event, the Clovis culture spread across North America (Waters and Stafford, 2007). Clovis-like fluted points have also been found in the Great Basin (Tuohy, 1985, 1986), and these points are almost always surface finds associated with valley settings (Beck and Jones, 1997) that once contained lakes or marshes (Grayson, 1993). In the Great Basin, buried fluted points have been discovered four times. The best age control obtained for a fluted point is a minimum limiting date of $10,320 \pm 50{ }^{14} \mathrm{C} \mathrm{BP}(12.1 \pm 0.1 \mathrm{ka})$, determined on charcoal located $13 \mathrm{~cm}$ above the point at the Sunshine locality in central western Nevada (Jones and Beck, 1996; Jones et al., 1996).

Great Basin western stemmed points have been found in the same contexts as fluted points, but they are more widely distributed and have ages ranging from $11,200 \pm 200{ }^{14} \mathrm{C} B P$ to $7240 \pm 150$ ${ }^{14} \mathrm{C} \mathrm{BP}(13.1 \pm 0.2$ to $8.1 \pm 0.1 \mathrm{ka}$ ) (see discussion on pages $192-194$ in Beck and Jones, 1997). Western stemmed points have also been found on the Columbia Plateau where the two oldest points come from the Cooper's Ferry site, Idaho, and are dated to $11,410 \pm 130$ and $11,370 \pm 40{ }^{14} \mathrm{C} \mathrm{BP}(13.3 \pm 0.1$ and $13.2 \pm 0.1 \mathrm{ka}$ ) (Davis and Schweger, 2004). Thus, the oldest stemmed points are equivalent to Clovis in age. Both fluted and stemmed projectile points have been found throughout the Lahontan Basin (Reno, 1985; Tuohy, 1989). 


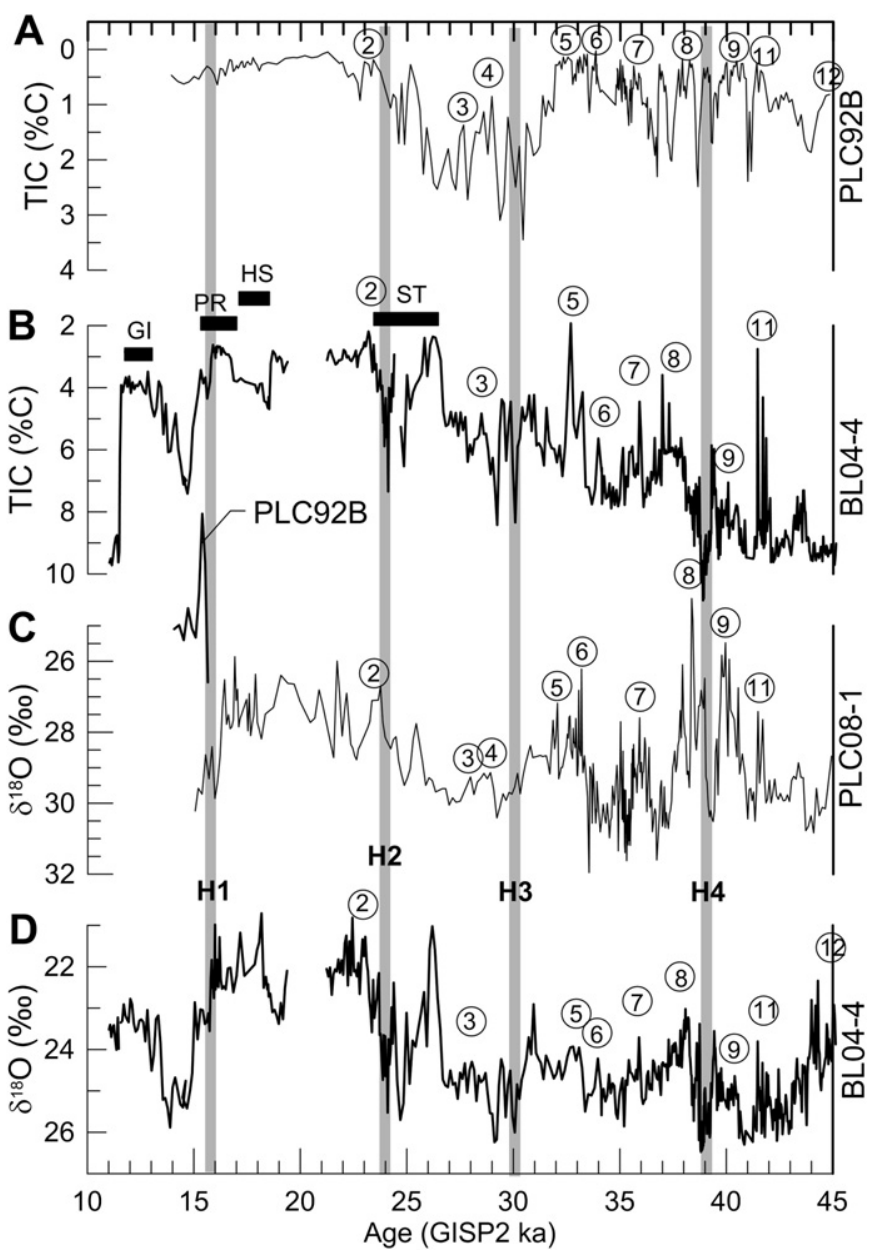

Fig. 20. Comparison of TIC and $\delta^{18} \mathrm{O}$ records from Lahontan and Bonneville Basin sediment cores dated using PSV-based age control. The Gilbert stillstand, Provo stillstand, Bonneville highstand and Stansbury Oscillation denoted by solid black rectangles are labeled, respectively, GI, PR, HS, and ST. Circled numbers refer to DO interstadials and $\mathrm{H}$ refers to Heinrich events.

It is possible that the pre-Clovis first Americans soon vacated the arid Great Basin during the extremely dry Bølling event (14.7-14.1 ka). On the other hand, pre-Clovis hunter gatherers may have moved to Great Basin wetlands that persisted during that interval, at least intermittently, at low elevations. If this was the case, rising lake levels during the subsequent Younger Dryas event may have eroded much of the evidence of the pre-Clovis/Stem Point tenure between 14.2 and $13.3 \mathrm{ka}$ in the Great Basin.

\section{Conclusions}

A PSV-based age model was applied to two shallow-water sediment cores from the Pyramid Lake basin in order to create a hydrologic-balance chronology for the period 48.0-13.9 ka. The Pyramid Lake hydrologic-balance record was extended to $11.5 \mathrm{ka}$, using TIC data from a ${ }^{14} \mathrm{C}$-calibrated Pyramid Lake deep water core. In addition, the calibrated ages and elevations of subaerially exposed carbonate deposits in the Pyramid and Winnemucca lake basins were used to constrain water depths between 48.0 and $11.1 \mathrm{ka}$.

Comparison of Pyramid Lake hydrologic-balance records $\left(\delta^{18} \mathrm{O}\right.$ and TIC) with the GISP2 $\delta^{18} \mathrm{O}$ record of North Atlantic airtemperature change indicates a certain degree of synchroneity of the lake and ice $\delta^{18} \mathrm{O}$ records between 48.0 and $11.5 \mathrm{ka}$. Prior to
$15.5 \mathrm{ka}$, some lake-isotopic maxima (dry events) appear associated with Heinrich cold events and some lake-isotopic minima (wet events) appear associated with Dansgaard-Oeschger interstadial oscillations. After $15.5 \mathrm{ka}$, the polarity of the Greenland-Lahontan teleconnection reverses with Lahontan wet events being associated with Greenland cold events; e.g., the Lahontan 13.3-11.7 ka wet event occurs at essentially the same time as the Youngest Dryas cold event.

The 30.0-15.5 ka period was a time when sea level was more than $80 \mathrm{~m}$ lower than today's level; this was a time when the LIS was at its maximum size and extent. It was also a time during which abnormally cold Heinrich events and abnormally warm DO oscillations were associated with, respectively, low and high lake levels in the Lahontan Basin.

A comparison of climate-proxy records $\left(\delta^{18} \mathrm{O}\right.$ and TIC) from sediment cores, whose age models were constructed using PSV, indicate a high degree of correlation between the Lahontan and Bonneville basins between 45 and $14 \mathrm{ka}$. TIC and $\delta^{18} \mathrm{O}$ minima in both basins could be associated with DO oscillations 11, 9-5, 3 and 2. In addition, a very wet climate characterized both basins between 24 and $16 \mathrm{ka}$ and both basins experienced large oscillations in lake volume during the Stansbury event.

The nature of the teleconnection linking North Atlantic and Great Basin climates remains arguable. Some authors have suggested that during the last glacial period, North Atlantic air temperatures oscillated in response to changes in strength of the Atlantic meridional overturning circulation (AMOC) when the production of North Atlantic Deep Water (NADW) decreased and(or) shifted to more southerly latitudes causing a decrease in heat exported by surface currents to the North Atlantic region (Ganopolski and Rahmstorf, 2001; Sarnthein et al., 2001; Elliot et al., 2002). Such changes in air temperature would have propagated downwind, influencing the pattern of sea-surface temperature anomalies in the North Pacific Ocean, which, in turn, affected the water-vapor flux to the overlying atmosphere as well as the trajectory of storm systems passing over the Pacific Ocean bringing precipitation to the Great Basin.

However, as the Laurentide Ice Sheet grew, it also altered the windfield over western North America (see, e.g., Kutzbach and Guetter, 1986). Recently, Wunsch (2006) has suggested the possibility that DO oscillations observed in Greenland ice were not generated by shifts in North Atlantic Ocean circulation, given the small contribution of heat from the high-latitude ocean to the overall meridional heat flux. Instead, Wunsch (2006) argues that DO oscillations were a consequence of the interactions of the windfield with Northern Hemisphere ice sheets and that the changes in ocean circulation were also a consequence of wind shifts.

Atmospheric simulations by Jackson (2000), Roe and Lindzen (2001), and Justino et al. (2005) support the concept that changes in ice sheet topography strongly influence the windfield. In addition, strengthening of the westerlies in the subtropical western North Atlantic during DO oscillations has been documented by López-Martínez et al. (2006). If DO oscillations were caused by changing ice sheet topography, surely Heinrich events also impacted the trajectory of the windfield, including the embedded polar jet stream which is associated with Great Basin precipitation.

Studies of marine sediments along the California coast indicate that cooling occurred along the West Coast during the Younger Dryas event (12.9-11.6 ka). Barron et al. (2003) produced climate records from marine core ODP 1019, taken just south of the OregonCalifornia border. At this site, minima in alkenone-based seasurface temperatures (SSTs) occurred during the Younger Dryas event. California margin studies of Behl and Kennett (1996) and Hendy et al. (2002) have shown that the Younger Dryas event 
corresponded to a sedimentary interval in core ODP 893A characterized by a peak in left-coiling Neogloboquadrina pachyderma (cooler SSTs), and an increase in foraminiferal $\delta^{18} \mathrm{O}$ values (cooler SSTs). Thus, temperatures along the Pacific Coast west of the Great Basin were relatively cold during the Younger Dryas event. In addition, MacDonald et al. (2008) used a chironomid-based thermometer to show that summer water temperatures in an eastcentral Sierra Nevada lake (Barrett Lake) were depressed during the Younger Dryas event. To the extent that this cooling reached the Great Basin it would account for some of the increase in effective wetness documented during the Younger Dryas event in the Lahontan and Bonneville basins (Oviatt et al., 2005); evaporation rates would have decreased as air temperatures lowered and relative humidities increased, decreasing the vapor pressure potential across the air-water interface.

Lake Lahontan achieved its highstand at $15.5 \mathrm{ka}$. Lake level fell precipitously over the next $300 \mathrm{y}$, resulting in a saline water body from which dolomite was precipitated. The lake remained at low elevations between 15.2 and $13.3 \mathrm{ka}$ and it was during this dry time that the first Americans appear to have entered the northern Great Basin. The severity of this climate either drove them out of the Great Basin or they populated the edges of low-elevation wetlands that persisted during the 1100-y dry period. Between 13.3 and 13.1, lakes in the Great Basin rose once more and oscillated in size during the subsequent Younger Dryas event. It is quite likely that these oscillations destroyed evidence of human occupation of lowelevation wetlands, creating the appearance of a cultural hiatus.

The Carson Sink Bed, which was deposited at 34.1 ka can be shown to be equivalent to Wilson Creek Ash 15, which was deposited during the Mono Lake magnetic excursion. This implies that the Mono Lake excursion occurred 7 ka after the Laschamp magnetic excursion and should not be confused with that excursion.

\section{Acknowledgments}

The authors thank the Pyramid Lake Paiute Tribe for allowing access to their tribal lands and waters. Our appreciation to Daniel Brothers for his review of an earlier version of this manuscript. Thanks also to Scott Starrett and two anonymous reviewers for their constructive comments on the manuscript. Benson is a USGS emeritus, an affiliate of the Institute of Arctic and Alpine Research and an adjunct curator of anthropology at the Museum of Natural History, University of Colorado.

\section{Appendix. Supplementary data}

Supplementary data associated with this article can be found, in the online version, at doi:10.1016/j.quaint.2012.02.040.

\section{References}

Adams, K.D., 2010. Lake levels and sedimentary environments during deposition of the Trego hot springs and Wono tephras in the Lake Lahontan Basin, Nevada, USA. Quaternary Research 73, 118-129.

Adams, K.D., Wesnousky, S.G., 1999. The Lake Lahontan Highstand: Age, Surficial Characteristics, Soil Development, and Regional Shoreline Correlation.

Aharon, P., Kolodny, Y., Sass, E., 1977. Recent hot brine dolomitization in the "solar Lake", Gulf of Elat, isotopic, chemical and mineralogical study. Journal of Geology 85, 27-48.

Alley, R.B., 2000. The Younger Dryas cold interval as viewed from central Greenland. Quaternary Science Reviews 19, 213-226.

Alley, R.B., Shuman, C.A., Meese, D.A., Gow, A.J., Taylor, K.C., Cuffey, K.M., Fitzpatrick, J.J., Grootes, P.M., Zielinski, G.A., Ram, M., Spinelli, G., Elder, B., 1997. Journal of Geophysical Research 102, 26,367-26,381.

Barron, J.A., Heusser, L., Herbert, T., Lyle, M., 2003. High-resolution climatic evolution of coastal northern California during the past 16,000 years. Paleoceanography 18 . $20-21$ to $20-14$.
Beck, C., Jones, G.T., 1997. The terminal Pleistocene/early Holocene archaeology of the Great Basin. Journal of World Prehistory 11, 161-236.

Behl, R.J., Kennett, J.P., 1996. Brief interstadial events in the Santa Barbara basin, NE Pacific, during the past 60 kyr. Nature 379, 243-246.

Benson, L., 1993. Factors affecting ${ }^{14} \mathrm{C}$ ages of lacustrine carbonates: timing and duration of the last highstand lake in the Lahontan Basin. Quaternary Research 39, 163-174.

Benson, L.V., 1994a. Stable isotopes of oxygen and hydrogen in the Truckee RiverPyramid lake surface-water system. 1. Data analysis and extraction of paleoclimatic information. Limnology and Oceanography 39, 344-355.

Benson, L., 1994b. Carbonate deposition, Pyramid Lake subbasin, Nevada: 1. Sequence of formation and elevational distribution of carbonate deposits (tufas). Palaeogeography, Palaeoclimatology, Palaeoecology 109, 55-87.

Benson, L., Paillet, F., 2002. HIBAL: a hydrologic-isotopic-balance model for application to paleolake systems. Quaternary Science Reviews 21, 1521-1539.

Benson, L.V., Thompson, R.S., 1987. Lake-level variation in the Lahontan basin for the past 50,000 years. Quaternary Research 28, 69-85.

Benson, L., Currey, D., Lao, L., Hostetler, S., 1992. Lake-size Variations in the Lahontan and Bonneville Basins Between 13,000 and $9000{ }^{14} \mathrm{C}$ BP

Benson, L.V., Kashgarian, M., Rubin, M., 1995. Carbonate deposition, Pyramid Lake subbasin, Nevada: 2. Lake levels and polar jet stream positions reconstructed from radiocarbon ages and elevations of carbonate deposits (tufas). Palaeogeography, Palaeoclimatology, Palaeoecology 117, 1-30.

Benson, L.V., White, L.D., Rye, R., 1996a. Carbonate deposition, Pyramid Lake subbasin, Nevada: 4. Comparison of the stable isotope values of carbonate deposits (tufas) and the Lahontan lake-level record. Palaeogeography, Palaeoclimatology, Palaeoecology 122, 45-76.

Benson, L.V., Burdett, J.W., Kashgarian, M., Lund, S.P., Phillips, F.M., Rye, R.O., 1996b. Climatic and hydrologic oscillations in the Owens Lake basin and adjacent Sierra Nevada, California. Science 274, 746-749.

Benson, L.V., Smoot, J.P., Kashgarian, M., Sarna-Wojcicki, A., Burdett, J.W., 1997. Radiocarbon ages and environments of deposition of the Wono and Trego Hot Springs tephra layers in the Pyramid Lake subbasin, Nevada. Quaternary Research 47, 251-260.

Benson, L.V., Lund, S.P., Burdett, J.W., Kashgarian, M., Rose, T.P., Smoot, J.P., Schwartz, M., 1998. Correlation of late Pleistocene lake-level oscillations in Mono Lake, California, with North Atlantic climate events. Quaternary Research 49, 1-10.

Benson, L., Kashgarian, M., Rye, R., Lund, S., Paillet, F., Smoot, J., Kester, C. Mensing, S., Meko, D., Lindstrom, S., 2002. Holocene multidecadal and multicentennial droughts affecting Northern California and Nevada. Quaternary Science Reviews 21, 659-682.

Benson, L., Liddicoat, J., Smoot, J., Sarna-Wojcicki, A., Negrini, R., Lund, S., 2003. Age of the Mono Lake excursion and associated tephra. Quaternary Science Reviews $22,135-140$.

Benson, L.V., Lund, S.P., Smoot, J.P., Rhode, D.E., Spencer, R.J., Verosub, K.L., Louderback, L.A., Johnson, C.A., Rye, R.O., Negrini, R.M., 2011. The rise and fall of Lake Bonneville between 45 and $10.5 \mathrm{ka}$. Quaternary International 235, 67-79.

Berger, G.W., Busacca, A.J., 1995. Thermoluminescence dating of late Pleistocene loess and tephra from eastern Washington and southern Oregon and implications for the eruptive history of Mount St. Helens. Journal of Geophysical Research 100, 22361-22374.

Bintanja, R., van de Wal, R.S.W., Oerlemans, J., 2005. Modelled atmospheric temperatures and global sea levels over the past million years. Nature 437, $125-128$

Davis, J.O., 1985. Correlation of late Quaternary tephra layers in a long pluvial sequence near Summer Lake, Oregon. Quaternary Research 23, 38-53.

Davis, L.G., Schweger, C., 2004. Geoarchaeological context of late Pleistocene and early Holocene occupation at the Cooper's Ferry site, western Idaho, USA Geoarchaeology: An International Journal 19, 685-704.

Dyke, A.S., Andrews, J.T., Clark, P.U., England, J.H., Miller, G.H., Shaw, J., Veillette, J.J., 2002. The Laurentide and Innuitian Ice Sheets during the Last Glacial Maximum. Quaternary Science Reviews 21, 9-32.

Elliot, M.L., Labeyrie, L., Duplessy, J.C., 2002. Changes in North Atlantic deep-water formation associated with the Dansgaard-Oeschger temperature oscillations (60-10 ka). Quaternary Science Reviews 21, 1153-1165.

Foit, F.F., Gavin, D.G., Hu, F.S., 2004. The tephra stratigraphy of two lakes in southcentral British Columbia, Canada and its implications for the mid-late Holocene volcanic activity at Glacier Peak and Mount St. Helens, Washington, USA. Canadian Journal of Earth Sciences 41, 1401-1410.

Ganopolski, A., Rahmstorf, S., 2001. Stability and variability of the thermohaline circulation in the past and future: a study with a coupled model of intermediate complexity. In: Seidov, D., Haupt, B.J., Maslin, M. (Eds.), The Oceans and Rapid Climate Change: Past, Present, and Future. American Geophysical Union, Washington, D. C., pp. 261-275.

Gilbert, M.T.P., Jenkins, D.L., Götherstrom, A., Naveran, N., Sanchez, J.J., Hofreiter, M. Thomsen, P.F., Binladen, J., Higham, T.F.G., Yohe II, R.M., Parr, R., Cummings, L.S. Willerslev, E., 2008. DNA from pre-Clovis human coprolites in Oregon, North America. Science 320, 786-789.

Grayson, D.K., 1993. The Desert's Past, a Natural Prehistory of the Great Basin. Smithsonian Institution Press, Washington.

Harvie, C.E., Weare, J.H., 1980. The prediction of mineral solubilities in natural waters; the $\mathrm{Na}-\mathrm{K}-\mathrm{Mg}-\mathrm{Ca}-\mathrm{Cl}-\mathrm{SO}_{4}-\mathrm{H}_{2} \mathrm{O}$ system from zero to high concentrations at $25{ }^{\circ} \mathrm{C}$. Geochimica et Cosmochimica Acta 44, 981-998. 
Hendy, I.L., Kennett, J.P., Roark, E.B., Ingram, B.L., 2002. Apparent synchroneity of submillennial scale climate events between Greenland and Santa Barbara Basin, California from 30-10 ka. Quaternary Science Reviews 21, 1167-1184.

Hostetler, S., Benson, L.V., 1990. Paleoclimatic implications of the high stand of Lake Lahontan derived from models of evaporation and lake level. Climate Dynamics 4, 207-217.

Jackson, C., 2000. Sensitivity of stationary wave amplitude to regional changes in Laurentide ice sheet topography in single-layer models of the atmosphere. Journal of Geophysical Research 105, 24,443-24,454.

Johnson, T.C., June 1980. Sediment redistribution by waves in lakes, reservoirs, and embayments. In: Proceedings of the Symposium on Surface Water Impoundments, vol. 791. American Society of Civil Engineers, Minneapolis, pp. 1307-1317.

Johnson, T.C., Lynch, E.L., Showers, W.J., Palczuk, N.C., 1988. Pleistocene fluctuations in the western boundary undercurrent on the Blake Outer Ridge. Paleoceanography 3, 191-207.

Jones, G.T., Beck, C., 1996. Paleoindian adaptations in eastern Nevada: the view from the sunshine locality. Paper Presented at the 25th Biennial Great Basin Anthropological Conference, Kings Beach, California, October 10-12.

Jones, G.T., Beck, C., LeTourneau, P.D., 1996. A possible association between Camelops cf. hesternus and lithic artifacts from the Sunshine Locality in eastern Nevada. Current Research in the Pleistocene 13, 27-29.

Justino, F., Timmermann, F., Merkel, U., Souza, E.P., 2005. Synoptic reorganization of atmospheric flow during the last glacial maximum. Journal of Climate 18 2826-2846.

Keigwin, L.D., Jones, G.A., 1994. Western North Atlantic evidence for millennialscale changes in ocean circulation and climate. Journal of Geophysical Research 99, 12,397-12,410.

Kempe, S., Kazmierczak, J., Landmann, G., Konuk, T., Reimer, A., Lipp, A., 1990. Largest know microbialites discovered in Lake Van, Turkey. Nature 349, 605-608.

Kent, D.V., Hemming, S.R., Turrin, B.D., 2002. Laschamp excursion at Mono Lake? Earth and Planetary Science Letters 197, 151-164.

Kutzbach, J.E., Guetter, P.J., 1986. The influence of changing orbital parameters and surface boundary conditions on climate simulations for the past 18000 years. Journal of Atmospheric Science 43, 1726-1759.

Lonsdale, P., 1977. Clustering of suspension-feeding macrobenthos near abyssal hydrothermal vents at oceanic spreading centers. Deep-Sea Research 24 857-863.

López-Martínez, C., Grimalt, J.O., Hoogakker, B., Gruetzner, J., Vautravers, M.J. McCave, N., 2006. Abrupt wind regime changes in the North Atlantic Ocean during the past $30,000-60,000$ years. Paleoceanography 21, PA4215. doi:10.1029/2006PA001275.

Lund, S.P., Keigwin, L., 1994. Measurement of the degree of smoothing in sediment paleomagnetic secular variation records: an example from late Quaternary deep-sea sediments of the Bermuda Rise, western North Atlantic Ocean. Earth and Planetary Science Letters 122, 317-330.

Lund, S.P., Williams, T., Acton, G., Clement, B., Okada, M., 2001a. Brunhes Epoch magnetic field excursions recorded in ODP Leg 172 sediments. In: Keigwin, L. Rio, D., Acton, G. (Eds.), 2001a. Proceedings of the Ocean Drilling Project, Scientific Results, vol. 172 (Chapter 10)

Lund, S.P., Acton, G. Clement, B., Okada, M., Williams, T., 2001b. Paleomagnetic records of Stage 3 excursions from ODP Leg 172 sediments. In: Keigwin, L. Rio, D., Acton, G. (Eds.), 2001b. Proceedings of the Ocean Drilling Project, Scientific Results, vol. 172 (Chapter 11).
MacDonald, G.M., Moser, K.A., Bloom, A.M., Porinchu, D.F., Potito, A.P., Wolfe, B.B., Edwards, TW.D., Petel, A, Orme, A.R. Orme, AJ, 2008. Evidence of temperature depression and hydrologic variations in the eastern Sierra Nevada during the Younger Dryas stade. Quaternary Research 70, 131-140.

Oviatt, C.G., Miller, D.M., McGeehin, J.P., Zachary, C., Mahan, S., 2005. The Younger Dryas phase of Great Salt Lake, Utah, USA. Palaeogeography, Palaeoclimatology, Palaeoecology 219, 263-284.

Reno, R.L., 1985. Clovis projectile points from Lahontan Reservoir and the Nevada Test Site, Nevada. Nevada Archaeologist 5, 7-18.

Roe, G.H., Lindzen, R.S., 2001. The mutual interaction between continental-scale ice sheets and atmospheric stationary waves. Journal of Climate 14, 1450-1465.

Rowan, D.J., Kalff, J., Rasmussen, J.B., 1992. Estimating the mud deposition boundary depth in lakes from wave theory. Canadian Journal of Fisheries and Aquatic Sciences 49, 2490-2497.

Sarna-Wojcicki, A.M., Lajoie, K.R., Meyer, C.E., Adam, D.P., Reick, H.J., 1991. Tephrochronologic correlation of upper Neogene sediments along the Pacific margin, conterminous United States. In: Morrison, R.B. (Ed.), 1991. Quaternary Non-Glacial Geology: Conterminous United States, vol. K-2. Geological Society of America, Decade of North American Geology, Boulder, Colorado, pp. $117-140$.

Sarnthein, M., Stattegger, K., Dreger, D., Erlenkeuser, H., Grootes, P., Haupt, B., Jung, S., Kiefer, T., Kuhnt, W., Pflaumann, U., Schäfer -Neth, C., Schulz, H., Schulz, M., Seidov, D., Simstich, J., van Kreveld-Alfane, S., Vogelsang, E., Völker, A., Weinelt, M., 2001. Fundamental modes and abrupt changes in North Atlantic circulation and climate over the last $60 \mathrm{ky}$ - concepts, reconstruction, and numerical modelling. In: Schäfer, P. (Ed.), The Northern North Atlantic: a Changing Environment. Springer Verlag, pp. 365-410.

Smoot, J.P., 1993. Field Trip Guide: Quaternary-Holocene Lacustrine Sediments of Lake Lahontan, Truckee River Canyon North of Wadsworth, Nevada. U.S. Geological Survey, Open-File Report 93-689, 35 p.

Smoot, J.P., Benson, L.V., 1998. Sedimentary structures as indicators of paleoclimatic fluctuations. Utah Geological Association Guidebook 26, 131-161.

Stuiver, M., Grootes, P.M., 2000. GISP2 Oxygen isotope ratios. Quaternary Research 53, 277-284.

Stuiver, M., Reimer, P.J., Reimer, R.W., 2005. CALIB 6.01 [WWW Program and Documentation]

Thompson, W.G., Goldstein, S.L., 2006. A radiometric calibration of the SPECMAP timescale. Quaternary Science Reviews 25, 3207-3215.

Tuohy, D.R., 1985. Notes on the Great Basin distribution of Clovis fluted and Folsom projectile points. Nevada Archaeologist 5, 15-18.

Tuohy, D.R., 1986. Errata and additional notes on the Great Basin distribution of Clovis fluted and Folsom projectile points. Nevada Archaeologist 5, 2-7.

Tuohy, D.R., 1989. Notes on a Clovis point from the Black Rock Desert, Nevada. Nevada Archaeologist 7, 11-13.

Vogel, J.S., Nelson, D.E., Southon, J.R., 1987. ${ }^{14} \mathrm{C}$ background levels in an accelerator mass spectrometry system. Radiocarbon $29,323-333$.

Waters, M.R., Stafford Jr., T.W., 2007. Redefining the age of Clovis: implications for the peopling of the Americas. Science 315, 1122-1126.

Wunsch, C., 2006. Abrupt climate change: an alternative view. Quaternary Research $65,191-203$.

Zimmerman, S.H., Hemming S.R., Kent, D.V. Searle, S.Y, 2006. Revised chronology for late Pleistocene Mono Lake sediments based on paleointensity correlation to the global reference curve. Earth and Planetary Science Letters 252, 94-106. 